Prepared in cooperation with the San Antonio River Authority, the Evergreen Underground Water Conservation District, and the Goliad County Groundwater Conservation District

\title{
Estimation of Streamflow Gains and Losses in the Lower San Antonio River Watershed, South-Central Texas, 2006-10
}

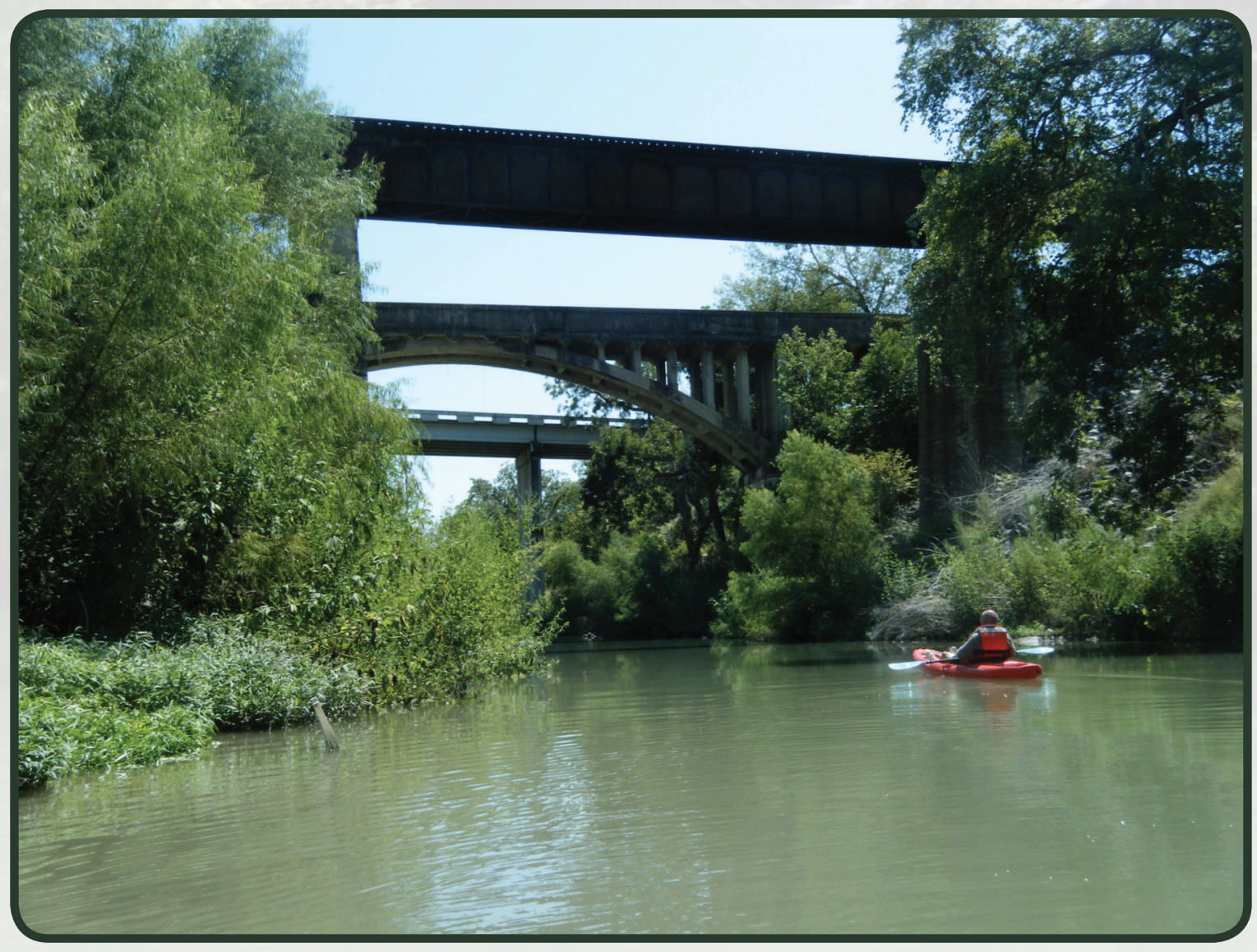

Scientific Investigations Report 2012-5073 
Cover: Photograph of U.S. Geological Survey hydrologist (Darwin Ockerman) kayaking upstream from U.S. Geological Survey streamflow-gaging station 08181500 Medina River at San Antonio, Texas, November 10, 2009 (photograph by Brian Petri, U.S. Geological Survey). 


\section{Estimation of Streamflow Gains and Losses in the Lower San Antonio River Watershed, South-Central Texas, 2006-10}

By Joy S. Lizárraga and Loren L. Wehmeyer

Prepared in cooperation with the San Antonio River Authority, the Evergreen Underground Water Conservation District, and the Goliad County Groundwater Conservation District

Scientific Investigations Report 2012-5073 


\title{
U.S. Department of the Interior \\ KEN SALAZAR, Secretary \\ U.S. Geological Survey \\ Marcia K. McNutt, Director
}

\section{U.S. Geological Survey, Reston, Virginia: 2012}

\author{
This and other USGS information products are available at http://store.usgs.gov/ \\ U.S. Geological Survey \\ Box 25286, Denver Federal Center \\ Denver, CO 80225 \\ To learn about the USGS and its information products visit http://www.usgs.gov/ \\ 1-888-ASK-USGS
}

\begin{abstract}
Any use of trade, product, or firm names is for descriptive purposes only and does not imply endorsement by the U.S. Government.

Although this report is in the public domain, permission must be secured from the individual copyright owners to reproduce any copyrighted materials contained within this report.
\end{abstract}

Suggested citation:

Lizárraga, J.S., and Wehmeyer, L.L., 2012, Estimation of streamflow gains and losses in the lower San Antonio River watershed, south-central Texas, 2006-10: U.S. Geological Survey Scientific Investigations Report 2012-5073, 34 p. 


\section{Contents}

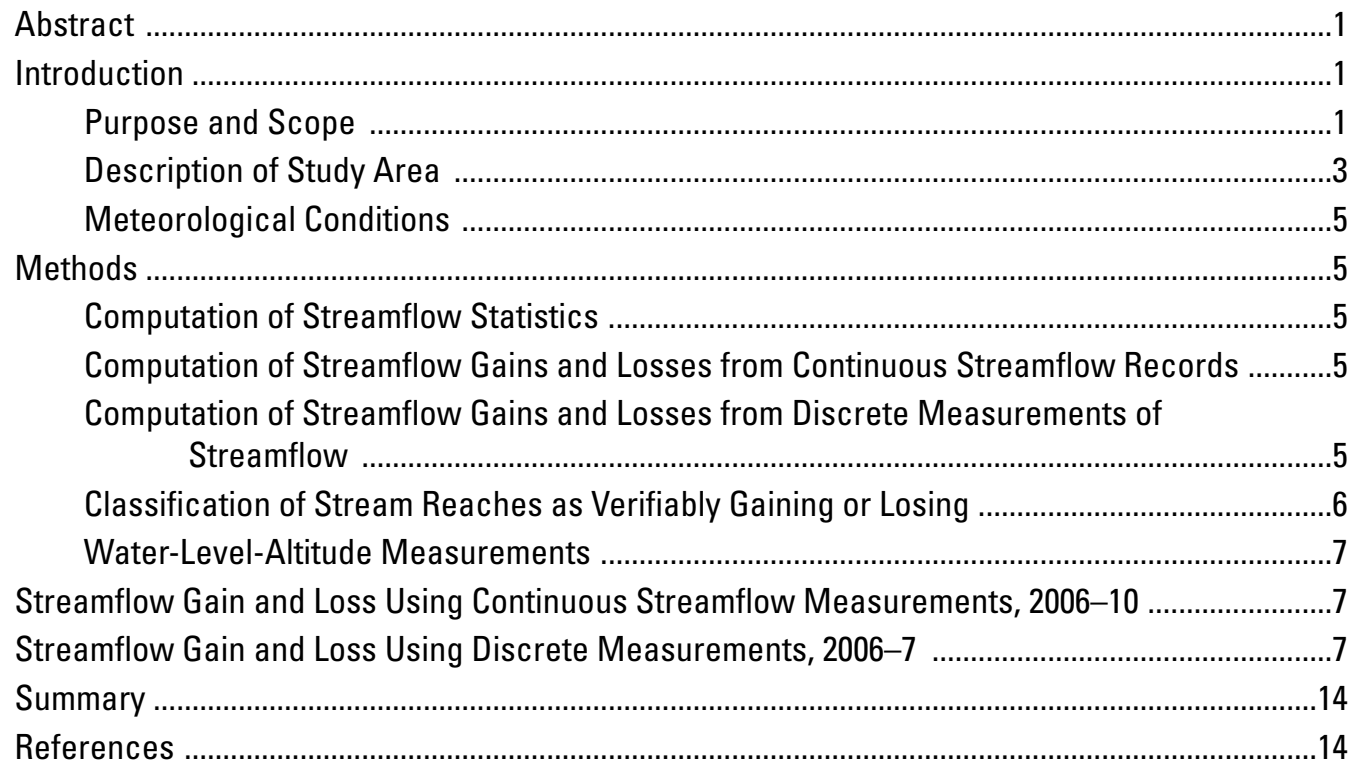

\section{Figures}

1. Map showing lower San Antonio River watershed in south-central Texas

2. Map showing aquifer systems, surficial geology, and delineation of water-budget zones of the lower San Antonio River watershed, south-central Texas

3. Graphs showing water-level altitudes measured in state wells and streamflow measured at the nearest downstream U.S. Geological Survey streamflow-gaging stations during 2006-8: A, State well 68-48-502 (site GW1) and U.S. Geological Survey streamflow-gaging station 08185500 Cibolo Creek at Sutherland Springs, Texas (site C7), B, State well 68-54-901 (site GW2) and U.S. Geological Survey streamflow-gaging station 08183200 San Antonio River near Floresville, Tex. (site C2), and C, State wells 79-21-705 and 79-21-706 (site identifier GW3 and GW4, respectively) and U.S. Geological Survey streamflow-gaging station 08188500 San Antonio River at Goliad, Tex. (site C10)

4. Graphs showing discrete streamflow measurements made along the main channel of the lower San Antonio River during four synoptic surveys: A, April 18-19, 2006, $B$, August 23-24, 2006, C, February 13-15, 2007, and D, October 9-11, 2007

5. Graphs showing discrete streamflow measurements made along the main channel of the Cibolo Creek during four synoptic surveys: $A$, April 18-19, 2006, $B$, August 23-24, 2006, C, February 13-15, 2007, and D, October 9-11, 2007

6. Maps showing verifiable streamflow gains and losses during four synoptic surveys in lower San Antonio River watershed: A, April 18-19, 2006; B, August 23-24, 2006; $C$, February 13-15, 2007; and $D, 0$ ctober 9-11, 2007, south-central Texas 


\section{Tables}

1. U.S. Geological Survey continuous and discrete measurement locations in the lower San Antonio River watershed, south-central Texas, 2006-10

2. Permitted wastewater discharges included in gain and loss estimations during 2006-10 in the lower San Antonio River watershed, south-central Texas

3. Annual rainfall, in inches, measured at three National Weather Service stations in or near the lower San Antonio River watershed, south-central Texas, 1960-2010

4. Active surface-water rights (2010) with diversion amounts used for gain or loss estimates during 2006-10 in lower San Antonio River watershed, south-central Texas

5. Discrete streamflow measurements at 20 locations in the lower San Antonio River watershed, south-central Texas, 2006-7

6. Average daily discharge of treated wastewater, in cubic feet per second, during synoptic streamflow measurement surveys, lower San Antonio River watershed, south Texas, 2006-10

7. Streamflow statistics for A, the period of record, and B, 2006-10, at U.S. Geological Survey streamflow-gaging stations in the lower San Antonio River, south-central Texas

8. Estimation of streamflow gain or loss during 2006-10 using continuous streamflowgaging stations in the lower San Antonio River watershed, south-central Texas

9. Estimated streamflow gains and losses for the main stem of the lower San Antonio River, south-central Texas, 2006-7

10. Estimated streamflow gains on the main stem of the lower San Antonio River, from Elemendorf, Texas, to Goliad, Tex., and from Goliad Tex., to McFaddin, Tex., southcentral Texas, 2006-7

11. Estimated streamflow gains and losses on the main stem of lower Cibolo Creek, Texas, 2006-7 


\section{Conversion Factors}

\section{Inch/Pound to SI}

\begin{tabular}{|c|c|c|}
\hline Multiply & By & To obtain \\
\hline \multicolumn{3}{|c|}{ Length } \\
\hline inch (in.) & 2.54 & centimeter $(\mathrm{cm})$ \\
\hline inch (in.) & 25.4 & millimeter $(\mathrm{mm})$ \\
\hline foot $(\mathrm{ft})$ & 0.3048 & meter $(\mathrm{m})$ \\
\hline mile (mi) & 1.609 & kilometer $(\mathrm{km})$ \\
\hline \multicolumn{3}{|c|}{ Area } \\
\hline square mile $\left(\mathrm{mi}^{2}\right)$ & 259.0 & hectare (ha) \\
\hline square mile $\left(\mathrm{mi}^{2}\right)$ & 2.590 & square kilometer $\left(\mathrm{km}^{2}\right)$ \\
\hline \multicolumn{3}{|c|}{ Flow rate } \\
\hline acre-foot per year (acre-ft/yr) & 1,233 & cubic meter per year $\left(\mathrm{m}^{3} / \mathrm{yr}\right)$ \\
\hline acre-foot per year (acre-ft/yr) & 0.001233 & cubic hectometer per year $\left(\mathrm{hm}^{3} / \mathrm{yr}\right)$ \\
\hline cubic foot per second $\left(\mathrm{ft}^{3} / \mathrm{s}\right)$ & 0.02832 & cubic meter per second $\left(\mathrm{m}^{3} / \mathrm{s}\right)$ \\
\hline $\begin{array}{l}\text { cubic foot per second per square } \\
\text { mile }\left[\left(\mathrm{ft}^{3} / \mathrm{s}\right) / \mathrm{mi}^{2}\right]\end{array}$ & 0.01093 & $\begin{array}{l}\text { cubic meter per second per square } \\
\text { kilometer }\left[\left(\mathrm{m}^{3} / \mathrm{s}\right) / \mathrm{km}^{2}\right]\end{array}$ \\
\hline million gallons per day $(\mathrm{Mgal} / \mathrm{d})$ & 0.04381 & cubic meter per second $\left(\mathrm{m}^{3} / \mathrm{s}\right)$ \\
\hline
\end{tabular}

Vertical coordinate information is referenced to the National Geodetic Vertical Datum of 1929 (NGVD 29).

Horizontal coordinate information is referenced to the North American Datum of 1983 (NAD 83).

Altitude, as used in this report, refers to distance above the vertical datum. 



\title{
Estimation of Streamflow Gains and Losses in the Lower San Antonio River Watershed, South-Central, Texas 2006-10
}

\author{
By Joy S. Lizárraga and Loren L. Wehmeyer
}

\section{Abstract}

The U.S. Geological Survey (USGS), in cooperation with the San Antonio River Authority, the Evergreen Underground Water Conservation District, and the Goliad County Groundwater Conservation District, investigated streamflow gains and losses during 2006-10 in the lower San Antonio River watershed in south-central Texas. Streamflow gains and losses were estimated using 2006-10 continuous streamflow records from 11 continuous streamflow-gaging stations, and discrete streamflow measurements made at as many as 20 locations on the San Antonio River and selected tributaries during four synoptic surveys during 2006-7. From the continuous streamflow records, the greatest streamflow gain on the lower San Antonio River occurred in the reach from Falls City, Tex., to Goliad, Tex. The greatest streamflow gain on Cibolo Creek during 2006-10 occurred in the reach from near Saint Hedwig, Tex., to Sutherland Springs, Tex. The San Antonio River between Floresville, Tex., and Falls City was the only reach that had an estimated streamflow loss during 2006-10. During all four synoptic streamflow measurement surveys, the only substantially flowing tributary reach to the main stem of the lower San Antonio River was Cibolo Creek. Along the main stem of the lower San Antonio River, verifiable gains larger than the potential measurement error were estimated in two of the four synoptic streamflow measurement surveys. These gaining reaches occurred in the two most downstream reaches of the San Antonio River between Goliad and Farm Road (FM) 2506 near Fannin, Tex., and between FM 2506 near Fannin to near McFaddin. There were verifiable gains in streamflow in Cibolo Creek, between La Vernia, Tex., and the town of Sutherland Springs during all four surveys, estimated at between 4.8 and $14 \mathrm{ft}^{3} / \mathrm{s}$.

\section{Introduction}

The lower San Antonio River is a vital water resource supporting human and ecological communities in south-central Texas. Understanding the spatial distribution and magnitude of streamflow gains and losses in the lower San Antonio River (fig. 1) is important to water-resource managers in the region.

Water usage in the San Antonio River watershed has undergone a rapid transformation during the past 50 years because of development, particularly in Bexar County, Tex. (Texas Instream Flow Program and San Antonio River Authority, 2009). The San Antonio River's streamflow has been increasingly augmented by return flows from municipal use within the City of San Antonio, Tex., and surrounding municipalities. The river has changed from a system driven predominantly by groundwater discharge to a system highly influenced by year-round treated wastewater discharges, intermittent discharges and withdrawals, and a variety of urban and rural land uses (Texas Instream Flow Program and San Antonio River Authority, 2009).

There is scant information available regarding streamflow gains and losses in the lower San Antonio River watershed. Although three streamflow gain-loss studies (1958, 1963, 1968) were completed on Cibolo Creek (Slade and others, 2002), streamflow gain-loss studies for the total length of the lower San Antonio River have not been done. Accordingly, the U.S. Geological Survey (USGS), in cooperation with the San Antonio River Authority, the Evergreen Underground Water Conservation District, and the Goliad County Groundwater Conservation District, evaluated streamflow gains and losses during 2006-10 in the lower San Antonio River watershed.

\section{Purpose and Scope}

The purpose of this report is to document estimated streamflow gains and losses in the lower San Antonio River watershed during 2006-10. Streamflow gains and losses were estimated using 2006-10 continuous streamflow records from 11 continuous USGS streamflow-gaging stations, and discrete streamflow measurements made at as many as 20 locations on the San Antonio River and selected tributaries during four synoptic streamflow measurement surveys during 2006-7 (19 and 20 measurement sites during April and August 2006, respectively, and 20 and 15 measurement sites during February and October 2007, respectively). 


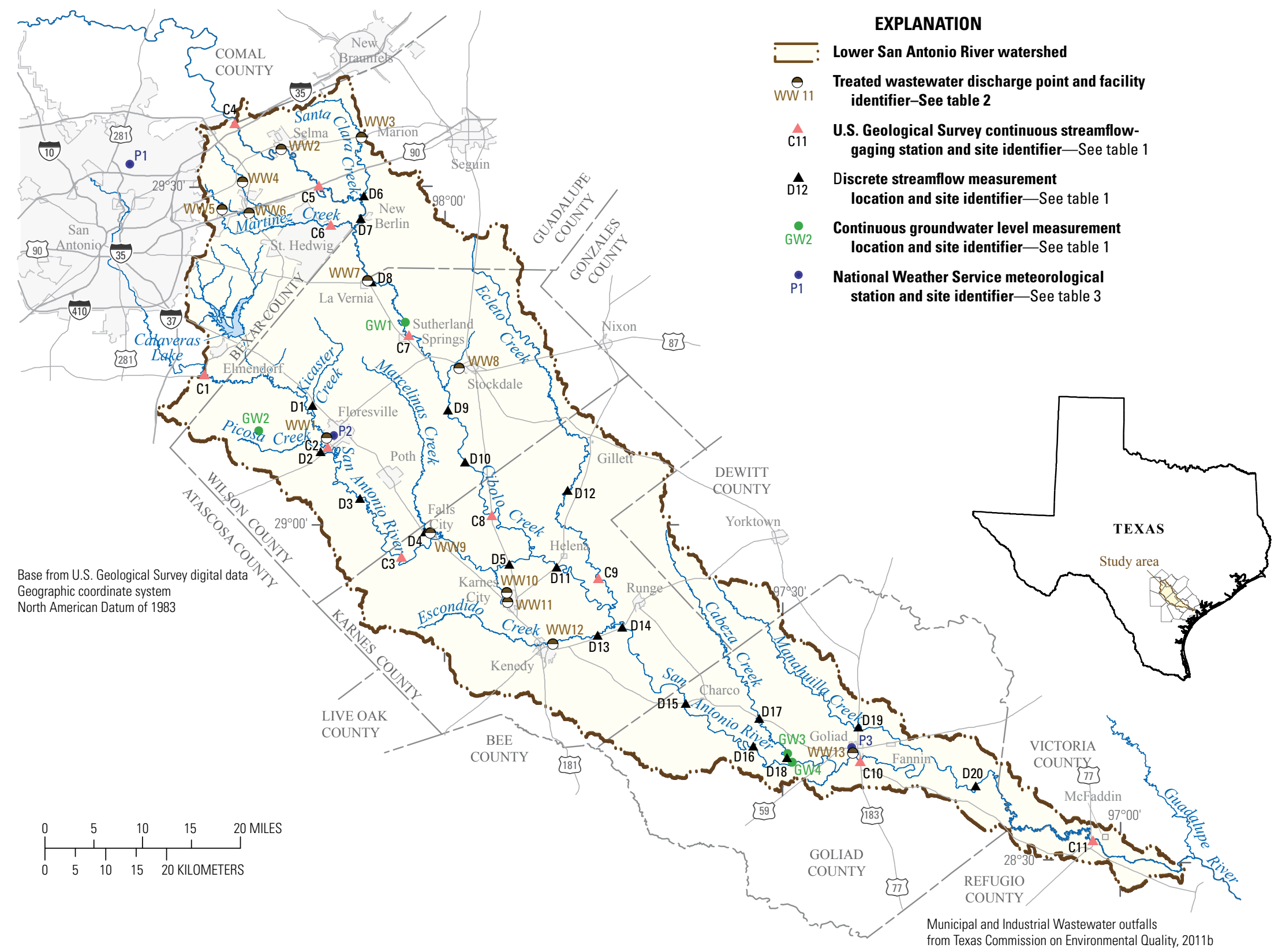

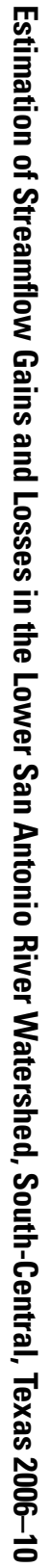

Figure 1. Lower San Antonio River watershed in south-central Texas. 


\section{Description of Study Area}

The study area (fig. 1) is defined as the 2,120 square mile $\left(\mathrm{mi}^{2}\right)$ contributing area to the San Antonio River downstream from USGS streamflow-gaging station 08181800 San Antonio River near Elmendorf, Tex. (site C1, fig. 1, table 1 at end of report), and downstream from USGS streamflowgaging station 08185000 Cibolo Creek at Selma, Tex. (site C4, fig. 1, table 1). The San Antonio River extends about 206 miles (mi) from site $\mathrm{C} 1$ to its confluence with the Guadalupe River. Major tributaries to the San Antonio River in the study area include Cibolo Creek, Ecleto Creek, Escondido Creek, Cabeza Creek, and Manahuilla Creek. Cibolo Creek begins in the study area as an ephemeral stream; streamflow at site $\mathrm{C} 4$ on Cibolo Creek occurs only in response to large runoff-producing storms north of the study area.

Six USGS streamflow-gaging stations with more than 40 years of continuous streamflow record are in the lower San Antonio River watershed (fig. 1, table 1):

1. 08181800 San Antonio River near Elmendorf, Tex. (site $\mathrm{C} 1$, table 1)

2. 08183500 San Antonio River near Falls City, Tex. (site $\mathrm{C} 3$, table 1)

3. 08188500 San Antonio River at Goliad, Tex. (site C10, table 1)

4. 08185000 Cibolo Creek at Selma, Tex. (site C4, table 1)

5. 08186000 Cibolo Creek near Falls City, Tex. (site C8, table 1)

6. 08186500 Ecleto Creek near Runge, Tex. (site C9, table 1).

To better understand streamflow gains losses in the study area, five additional continuous USGS streamflow-gaging stations were established in late 2005 and early 2006 (fig. 1):

1. 08183200 San Antonio River near Floresville, Tex. (site $\mathrm{C} 2$, table 1)

2. 08188570 San Antonio River near McFaddin, Tex. (site C11, table 1)

3. 08185065 Cibolo Creek near Saint Hedwig, Tex. (site C5, table 1)

4. 08185500 Cibolo Creek at Sutherland Springs (site C7, table 1)

5. 08185100 Martinez Creek near Saint Hedwig, Tex. (site C6, table 1).

The study area is less than 5 percent urbanized (Lizárraga and Ockerman, 2010), but the hydrology of the study area is affected by the rapidly growing San Antonio metropolitan area (fig. 1), which is mostly upstream. Groundwater discharge from springs has historically contributed to the base flow in the lower San Antonio River (Texas Instream Flow Program and San Antonio River Authority, 2009). The groundwater discharge from springs largely originates upstream from the study area, and from springs near Sutherland Springs, Tex., between sites D7 and C7 of Cibolo Creek (discrete measurements of streamflow were measured at sites D1 through D20 [fig. 1, table 1]). In recent years, flow in the river has been increasingly augmented by the discharge of treated wastewater.

The streamflow at site $\mathrm{C} 1$ (upstream drainage area of $1,740 \mathrm{mi}^{2}$ ) consists primarily of stormwater runoff, treated wastewater discharges, and groundwater discharge (Ockerman and McNamara, 2003). Streamflow into the study area at site $\mathrm{C} 4$ (upstream drainage area of $274 \mathrm{mi}^{2}$ ) only occurs after heavy rainfall north of the study area. Treated wastewater from the San Antonio metropolitan area discharges primarily to the San Antonio River upstream from Elmendorf, Tex., but some of the treated wastewater from the San Antonio metropolitan area is discharged into Cibolo Creek and its tributary, Martinez Creek. Cibolo Creek is a perennially flowing stream at site C7 because of treated wastewater discharges and springflow near the town of Sutherland Spring. Cibolo Creek flows into the lower San Antonio River near Helena, Tex. Treated wastewater discharges from smaller urban areas within the study area also affect the streamflow at various locations downstream from Saint Hedwig and Elmendorf. Permitted discharges of treated wastewater in the study area that were used in the assessment of streamflow gains and losses are listed in table 2, at end of report.

Lizárraga and Ockerman (2010, p. 4) noted "The northern tip of the lower San Antonio River watershed overlies Cretaceous rocks of the Edwards-Trinity aquifer system. The remainder of the watershed overlies the Texas Coastal Uplands and Coastal Lowlands aquifer systems (Ryder, 1996)" (fig. 2). The Texas Coastal Uplands aquifer system is composed of formations of Paleocene and Oligocene age, and the Texas Coastal Lowlands aquifer system is composed of younger formations from Oligocene through Holocene age. Lizárraga and Ockerman (2010) grouped the formations composing the aquifer systems in the study area into nine surficial geology zones (fig. 2). The surficial geology is shown in figure 2. These zones provide a common frame of reference for analysis in this report and comparison to modeling results in Lizárraga and Ockerman (2010). Formations gently dip and thicken toward the southeastern part of the study area (Young and others, 2010; Ryder, 1996).

The San Antonio River channel has become increasingly incised since the 1950s from site $\mathrm{C} 1$ to $\mathrm{C} 10$ and there are few active flood plains in this area (Cawthon, 2008; Engel, 2008). The San Antonio River downstream from site C10 crosses the outcrop of the Lissie Formation (fig. 2) and is wider and more prone to channel migration than upstream from site $\mathrm{C} 10$. Approaching the southeastern part of the study area (zone 9), there is a wider, more active flood plain. With an increasingly active flood plain and sandy soils, bank and alluvial water storage increases downstream from site $\mathrm{C} 10$. 


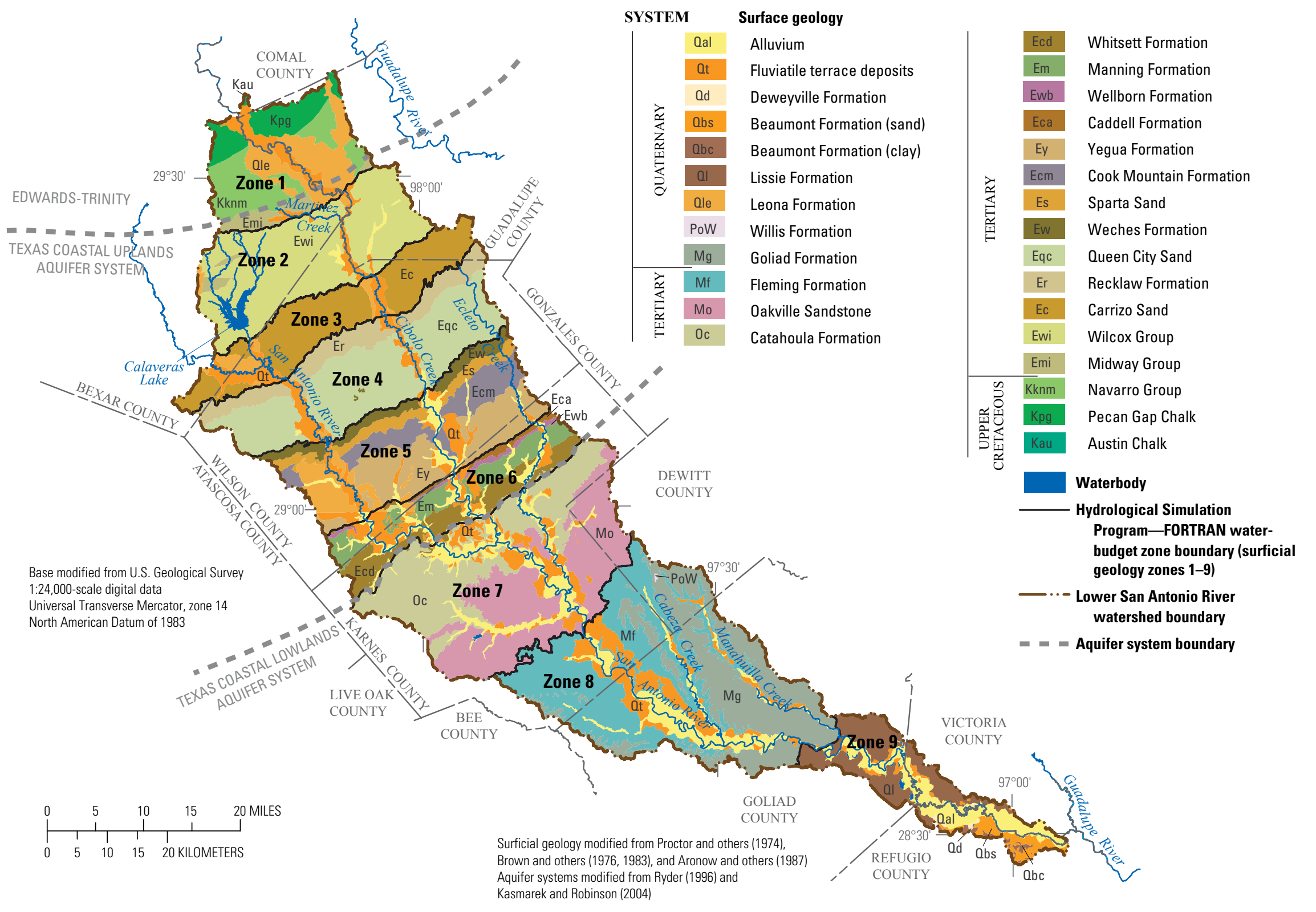

Figure 2. Aquifer systems, surficial geology, and delineation of water-budget zones of the lower San Antonio River watershed, south-central Texas. 


\section{Meteorological Conditions}

The climate of the northwestern part of the study area is subtropical subhumid transitioning into subtropical humid in the southeastern part of the study area (Larkin and Bomar, 1983). Heavy rainfall in the study area is common and can occur any time throughout the year. The 24-hour rainfall total corresponding to the 50-percent annual exceedance probability in Karnes County, Tex., is 4.2 inches (in.) (Natural Resources Conservation Service, 2009); Karnes County is at about the midpoint of the study area. Over a long period of record, a bimodal pattern in rainfall has been observed with wet periods in the late spring and mid-fall (Engel, 2008). During 2006-10, rainfall recorded at three rainfall stations shows generally increasing amounts from northwest to southeast in the study area, in the downstream direction (table 3 at end of report). During 2006-10, a wide range of annual rainfall amounts was measured, representing almost the entire range of annual rainfall variability recorded since 1960 at these stations.

\section{Methods}

Continuous streamflow records and discrete streamflow measurements were used to evaluate streamflow gains and losses in the lower San Antonio River watershed from Comal County, Tex., downstream to Refugio County, Tex. The discussion of methods pertaining to discrete measurements of streamflow is modified from Turco and others (2007, p. 5-7).

\section{Computation of Streamflow Statistics}

To determine whether the lower San Antonio River and lower Cibolo Creek generally gain or lose streamflow in the downstream direction, streamflow statistics were calculated for each of the 11 continuous USGS streamflow-gaging stations in the study area (table 1; sites C1 through C11). Daily streamflow statistics (average streamflow, 80-percent exceedance probability streamflow, 50-percent exceedance probability streamflow, 20-percent exceedance probability streamflow, and 10-percent exceedance probability streamflow) were computed for period of record at each station and for January 1, 2006, through December 31, 2010, using data obtained from the USGS National Water Information System (U.S. Geological Survey, 2011a).

\section{Computation of Streamflow Gains and Losses from Continuous Streamflow Records}

Streamflow gains and losses were first computed from records of continuous streamflow measured at 11 USGS streamflow-gaging stations (table 1 ; sites $\mathrm{C} 1$ through $\mathrm{C} 11$ ) in the study area. Streamflow gains and losses over the length of a stream reach were computed indirectly by calculating the differences in streamflow between continuous streamflowgaging stations along the stream. Sources of gains or losses between two sites (which define a reach), in addition to groundwater inflow or outflow through the streambed, include tributary inflow, diversions, return flows, and evaporation. Using these factors, streamflow gain or loss in the reach using continuous streamflow measurements was computed as

$$
G=Q_{D}-Q_{U}-I+D_{w r}-R+E,
$$

where

$$
\begin{aligned}
& G \quad \text { is streamflow gain or loss (groundwater } \\
& \text { inflow or outflow); } \\
& Q_{D} \quad \text { is measured streamflow at the downstream } \\
& \text { boundary of the reach; } \\
& Q_{U} \quad \text { is measured streamflow at the upstream } \\
& \text { boundary of the reach; } \\
& I \text { is measured inflows from tributaries; } \\
& D_{w r} \quad \text { is active surface-water rights (diversions) } \\
& \text { from the reach; } \\
& R \quad \text { is return flows to the reach; and } \\
& E \text { is evaporation. }
\end{aligned}
$$

During this study, numerous tributary inflows were measured directly and annual active surface-water rights diversions (table 4 at end of report) were acquired from the Texas Commission on Environmental Quality (2010). Active surface-water rights are not measured diversions. Over the 5-year period from 2006-10, actual diversions were approximated by 2010 active surface-water rights because on an annual basis, water rights in Texas generally are exercised so they are not lost (Townsend, 1986). However, return flows and evaporation were not measured during 2006-10. Return flows for 2006-10 were estimated as the 2008 annual withdrawal amount reported to the U.S. Environmental Protection Agency (U.S. Environmental Protection Agency, 2010). Evaporation was excluded from equation 1 for the gain and loss computation using continuous streamflow measurements in the lower San Antonio River watershed 2006-10. The magnitude of error associated with the exclusion of evaporation is believed to be minor when compared to potential errors associated with the flow measurements (Turco and others, 2007).

\section{Computation of Streamflow Gains and Losses from Discrete Measurements of Streamflow}

In addition to computing streamflow gains and losses from records of continuous streamflow measured at USGS streamflow-gaging stations during 2006-10, streamflow data for computation of gains and losses were collected from the San Antonio River and nine tributaries to the San Antonio River during four synoptic streamflow measurement surveys: April 18-19, 2006, August 23-24, 2006, February 13-15, 2007, and October 9-11, 2007 (table 5 at end of report). The four surveys were representative of various hydrologic conditions. During 2006 and 2007, discrete measurements 
of streamflow were made at sites D1 through D20 (fig. 1, table 5). During the April 18-19, 2006, survey, streamflow was measured at 19 sites, 7 on the San Antonio River and 12 on tributaries (fig. 1; table 1). During the August 23-24, 2006, and October 9-11, 2007, surveys, streamflow measurements were made at 20 sites, 7 on the San Antonio River and 13 on tributaries. During the February 13-15, 2007, survey, streamflow measurements were made at 15 sites, 3 on the San Antonio River and 12 on tributaries. When it was possible, average daily discharges of treated wastewater in the study area were obtained for the days of synoptic streamflow measurement surveys (table 6 at end of report).

Discrete measurements of streamflow were made in accordance with USGS methods (Rantz and others, 1982; Turnipseed and Sauer, 2010). Where conditions allowed (that is, when water depths were generally less than 3 feet), streams were waded and velocity measurements were made using rodmounted acoustic meters (Xylem Analytics, 2012). In all other instances, boat-mounted acoustic Doppler current profilers were used to measure streamflow (Oberg and others, 2005). Streamflow measurements were made during relatively stable base-flow conditions. By conducting the surveys in this manner, any streamflow gain or loss was unlikely to be attributed to rainfall.

Streamflow gains and losses over the length of a stream reach using discrete measurements were computed indirectly by calculating the differences in streamflow between sites along the stream. Sources of gains or losses between two sites, which define a reach, in addition to groundwater inflow or outflow through the streambed, include tributary inflow, diversions, return flows, and evaporation. Using these factors, streamflow gain or loss in the reach was computed as

$$
G=Q_{D}-Q_{U}-I+D-R+E
$$

where

$$
\begin{array}{cl}
G & \begin{array}{c}
\text { is streamflow gain or loss (groundwater } \\
\text { inflow or outflow); }
\end{array} \\
Q_{D} & \begin{array}{c}
\text { is measured streamflow at the downstream } \\
\text { boundary of the reach; }
\end{array} \\
Q_{U} & \begin{array}{c}
\text { is measured streamflow at the upstream } \\
\text { boundary of the reach; }
\end{array} \\
I & \begin{array}{c}
\text { is measured inflows from tributaries; } \\
D
\end{array} \quad \begin{array}{l}
\text { is measured outflows (diversions) from the } \\
\text { reach; }
\end{array} \\
R & \begin{array}{l}
\text { is return flows to the reach; and } \\
E
\end{array} \\
\text { is evaporation. }
\end{array}
$$

During this study, numerous tributary inflows and return flows were measured directly. However, diversions and evaporation were not measured, and those components were excluded from equation 2 for the gain and loss computation using discrete measurements. The magnitude of error associated with the exclusions of diversions and evaporation is believed to be minor when compared to potential errors associated with the flow measurements. Diversion amounts were not used in the gain and loss equation used for the computation using discrete measurements because information concerning actual diversions at the temporal scale of the synoptic streamflow measurement surveys cannot be approximated by active surface-water rights. Reaches were defined using the locations of the continuous stations as well as the locations of streamflow measurements made during four synoptic streamflow measurement surveys in April 2006, August 2006, February 2007, and October 2007.

\section{Classification of Stream Reaches as Verifiably Gaining or Losing}

For this report, a stream reach was classified as verifiably gaining or losing only when the streamflow gain or loss in a reach was greater than the sum of the potential errors associated with the upstream and downstream flow measurements. Streamflows used in gain-loss estimations included computed streamflows measured at continuously-recording USGS streamflow-gaging stations (fig. 1, table 1, sites $\mathrm{C} 1$ through $\mathrm{C} 11)$ and discrete measurements of streamflow made at additional locations (fig. 1, table 1, sites D1 through D20) during the synoptic streamflow measurement surveys. Computed streamflows at continuously-recording streamflow-gaging stations were based on river stage and an established rating curve that relates stage to streamflow. The rating curve was evaluated regularly using field measurements in accordance with U.S. Geological Survey protocols (Kennedy, 1984; Turnipseed and Sauer, 2010). For continuously-recording streamflow-gaging stations, the potential error was defined by the corresponding annual accuracy rating by water year (U.S. Geological Survey, 2011b). An annual accuracy rating of "excellent" for a station indicates that 95 percent of the daily discharges in that water year were considered to be within 5 percent of the true value. An accuracy rating of "good" indicates that 95 percent of the daily discharges in that water year were considered to be within 10 percent of the true value, "fair" indicates that 95 percent of the daily discharges in that water year were considered to be within 15 percent of the true value, and records that are considered to be less accurate are rated "poor" (Novak, 1985).

Discrete streamflow measurement error was based on the rating of the streamflow measurement (excellent, good, fair, or poor) by the streamgager (Sauer and Meyer, 1992; Turnipseed and Sauer, 2010). The rating is based on factors such as crosssection uniformity, velocity homogeneity, streambed conditions, and other factors that affect the accuracy of the measurement. Measurements rated excellent are believed to be within 2 percent of the true value, good are believed to be within 5 percent of the true value, fair are believed to be within 8 percent of the true value, and poor are believed to differ from the true value by more than 8 percent.

Diurnal variation in streamflow was defined as the highest and lowest hourly streamflow values during the synoptic streamflow-measurement surveys. Diurnal variation was not accounted for in the computations of streamflow gains or losses. Streamflow gains and losses computed for each reach 
were normalized by the contributing drainage area. The contributing drainage area to a reach was defined as the difference between the drainage area at the upstream and downstream sites. The gain or loss normalized by drainage area was computed as the gain or loss divided by the total contributing drainage area to the reach.

\section{Water-Level-Altitude Measurements}

Understanding surface-water/groundwater interactions is useful in gain-loss studies. Groundwater often adds to streamflow; conversely, formations composing the recharges zones of aquifers can remove water from streams. The importance of groundwater varies with local differences in geology and the degree of connection between the stream and the underlying formations (U.S. Geological Survey, 1999). Groundwater water-level altitudes were monitored continuously in four wells in the study area during 2006-8 (two completed in the Texas coastal uplands aquifer system and two in the Texas coastal lowlands aquifer system) to help determine if groundwater contributions to streamflow or streamflow contributions to recharge occurred in the study area. Four State wells, two in the Texas coastal uplands aquifer system and two in the Texas coastal lowlands aquifer system, were monitored from 2006 through 2008. The four groundwater stations instrumented to record continuous groundwater-level altitudes were State wells 68-48-502, 68-54-901, 79-21-705, and 79-21-706 (sites GW1 through GW4, fig. 1, table 1). The well depths are 243, 56.27, 983 , and 150 feet below land surface, respectively.

Continuous water-level altitudes were measured with a pressure transducer using methods described by Cunningham and Schalk (2011). The pressure transducers measure the depth to the water surface below a land-surface datum and are reported as the depth below the land-surface datum or watersurface elevation above the National Geodetic Vertical Datum of 1929 (NGVD 29). The continuous water-level altitudes were recorded every 15 minutes and transmitted hourly by way of satellite to the USGS National Water Information System (NWIS) database (U.S. Geological Survey, 2011a). Continuous daily water-level altitudes were periodically verified during field visits using methods described by Cunningham and Schalk (2011). Depth to groundwater was measured at each well with a steel tape or an electronic water-level contact tape (e-line) at least 15 separate times between July 20, 2006, and November 13, 2008. USGS station numbers corresponding to all State well numbers used in this report are shown in table 1.

\section{Streamflow Gain and Loss Using Continuous Streamflow Measurements, 2006-10}

Streamflow statistics at 11 U.S. Geological Survey continuous streamflow-gaging stations (tables $7 \mathrm{a}$ and $7 \mathrm{~b}$ at end of report) indicate that the lower San Antonio River and lower Cibolo Creek (fig. 1) generally gain streamflow in the downstream direction. The x-percent exceedance streamflow is defined as the daily average streamflow that was exceeded $\mathrm{x}$-percent of the days during the analysis period. For example, the 50-percent exceedance streamflow represents the daily average streamflow that was exceeded 50 percent of the days during the period of analysis - either the period of record for the station (table 7a) or during 2006-10 (table 7b).

From the continuous streamflow records, the greatest streamflow gain on the lower San Antonio River occurred in the reach from site $\mathrm{C} 3$ to site $\mathrm{C} 10$ (it also was the longest reach, and has several tributary inflows). The greatest streamflow gain on Cibolo Creek during 2006-10 occurred in the reach from site $\mathrm{C} 5$ to site $\mathrm{C} 7$ (table 8 at end of report). When normalized by drainage area, the reaches in the study area with the greatest estimated streamflow gains per unit area were Martinez Creek from the headwaters to site C6, and the San Antonio River between site C10 and site C11. The San Antonio River between site $\mathrm{C} 2$ and site $\mathrm{C} 3$ was the only reach that had an estimated streamflow loss during 2006-10.

\section{Streamflow Gain and Loss Using Discrete Measurements, 2006-7}

During both 2006 synoptic streamflow measurement surveys, streamflow measurements were made more than 2 weeks after measured rainfall occurred within the study area. During the 2007 surveys, small amounts of rainfall in the 2 weeks prior to streamflow measurements could not be avoided. Rainfall of 0.3 in. was measured on February 12, 2007, at the National Weather Service station in Goliad (site P3, fig. 1, table 3), approximately 12 days prior to the February 2007 sampling, and rainfall of 0.5 in. was measured at the National Weather Service station in Goliad on the first day of the October 2007 survey, following 29 days of no measurable rainfall. Streamflow and groundwater changes in response to the rainfall preceding the 2007 surveys were minimal; stream height above an arbitrary datum (stream stage) did not rise substantially at the continuous streamflowgaging stations (sites $\mathrm{C} 1-\mathrm{C} 11$; fig. 1, table 1) and groundwater water-level altitudes at sites GW1 through GW4 (fig. 1, table 1) remained relatively stable during the 2007 survey periods (fig. 3). For example, water-level altitudes at site GW1 (fig. 3) declined about 0.02 percent, and streamflows at site $\mathrm{C} 10$ and site $\mathrm{C} 11$ (fig. 3) fell about 6.6 and 3.1 percent, respectively, from October 7-12, 2007, indicating a minimal groundwater and surface-water response to rainfall during the week prior to the October survey.

During all four synoptic streamflow measurement surveys, the only substantially flowing tributary reach to the main stem of the lower San Antonio River was Cibolo Creek. Tributaries of the main channel of the San Antonio River, with the exception of Cibolo Creek, were not flowing 

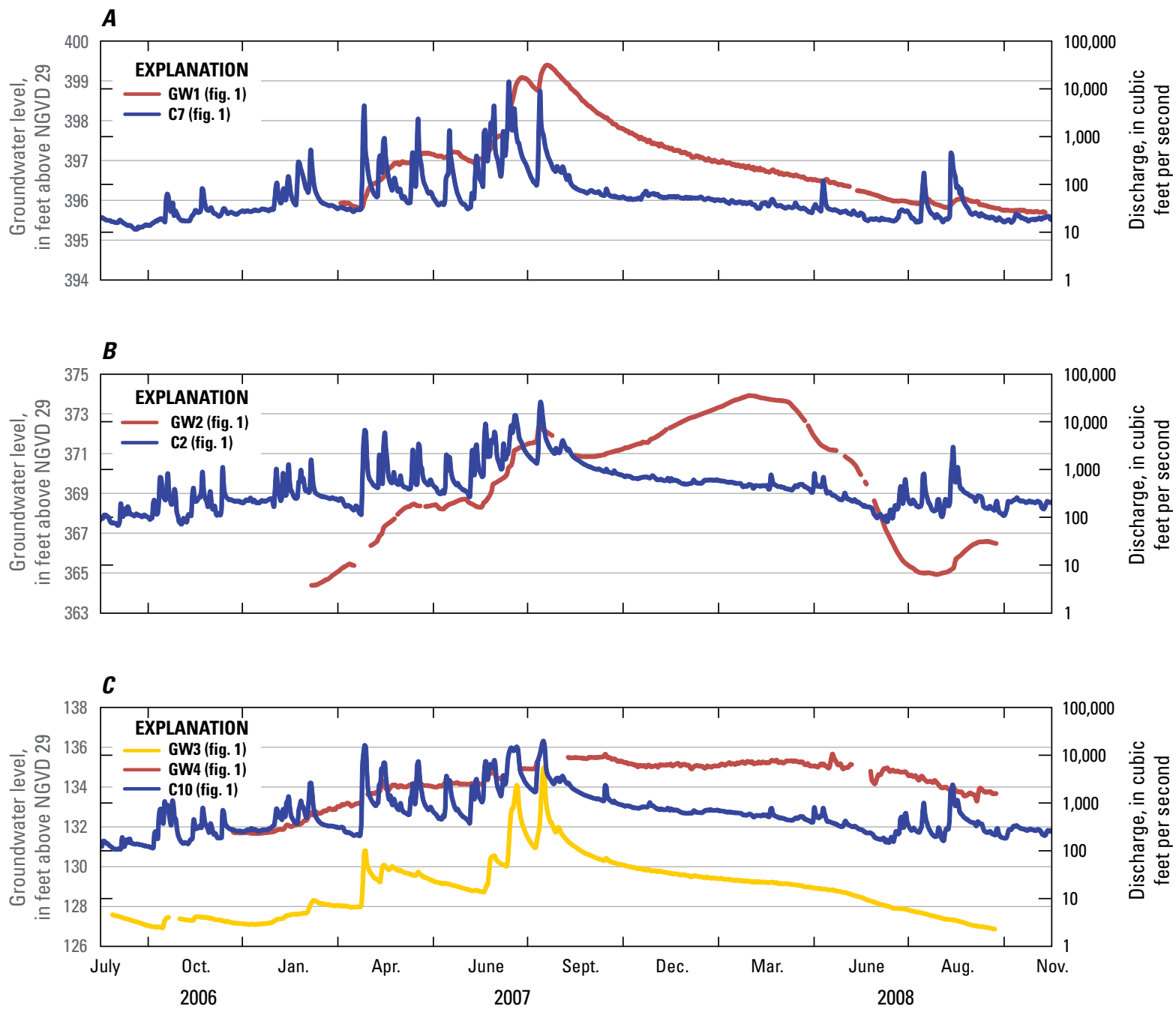

Figure 3. Water-level altitudes measured in state wells and streamflow measured the nearest downstream U.S. Geological Survey streamflow-gaging stations during 2006-8: $A$, State well 68-48-502 (site GW1) and U.S. Geological Survey streamflow-gaging station 08185500 Cibolo Creek at Sutherland Springs, Texas (site C7), B, State well 68-54-901 (site GW2) and U.S. Geological Survey streamflowgaging station 08183200 San Antonio River near Floresville, Tex. (site C2), and C, State wells 79-21-705 and 79-21-706 (site identifier GW3 and GW4, respectively) and U.S. Geological Survey streamflow-gaging station 08188500 San Antonio River at Goliad, Tex. (site C10).

or only minimally flowing during the 2006 and 2007 synoptic streamflow measurement surveys. The three tributaries to the San Antonio River overlying the Texas coastal uplands and Texas coastal lowlands aquifer system (Cabeza Creek, Escondida Creek, and Manahuilla Creek) were flowing during the October 2007 survey but each contributed only 3.0 to $4.5 \mathrm{ft}^{3} / \mathrm{s}$ (table 5), a small percentage of the overall flow in the San Antonio River. Although there was rainfall in the study area prior to the October 2007 survey, streamflow declined slowly at the San Antonio River streamflow-gaging stations throughout the October sampling period (fig. 3). This declining streamflow could be an indication that the river was still adjusting from heavier rains earlier in the year; large amounts of rain fell on the study area during May-August 2007 (National Climatic Data Center, 2011).

During the synoptic streamflow measurement survey periods, there was a diurnal fluctuation in streamflow in the San Antonio River and Cibolo Creek. It was unknown whether discrete measurements were made on the high end or low end of a diurnal fluctuation. Therefore, ranges of hourly streamflows at the continuous measurement stations during the four synoptic surveys are presented (fig. 4; fig. 5). Most of the gain in the main channel of the lower San Antonio River (fig. 4) occurred gradually except for an abrupt increase at the 

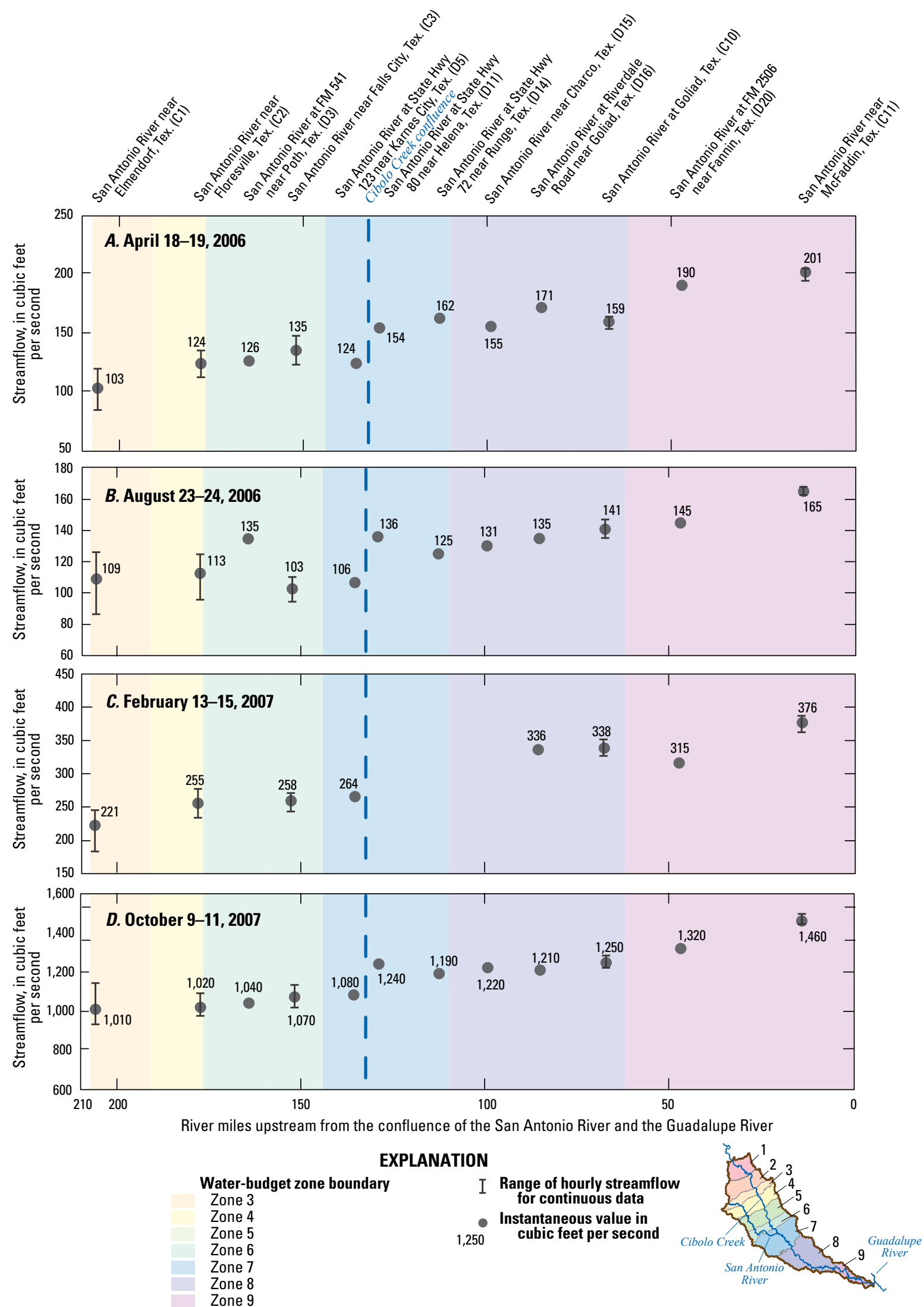

Figure 4. Discrete streamflow measurements made along the main channel of the lower San Antonio River during four synoptic surveys: $A$, April 18-19, 2006, $B$, August 23-24, 2006, C, February 13-15, 2007, and D, October 9-11, 2007. 

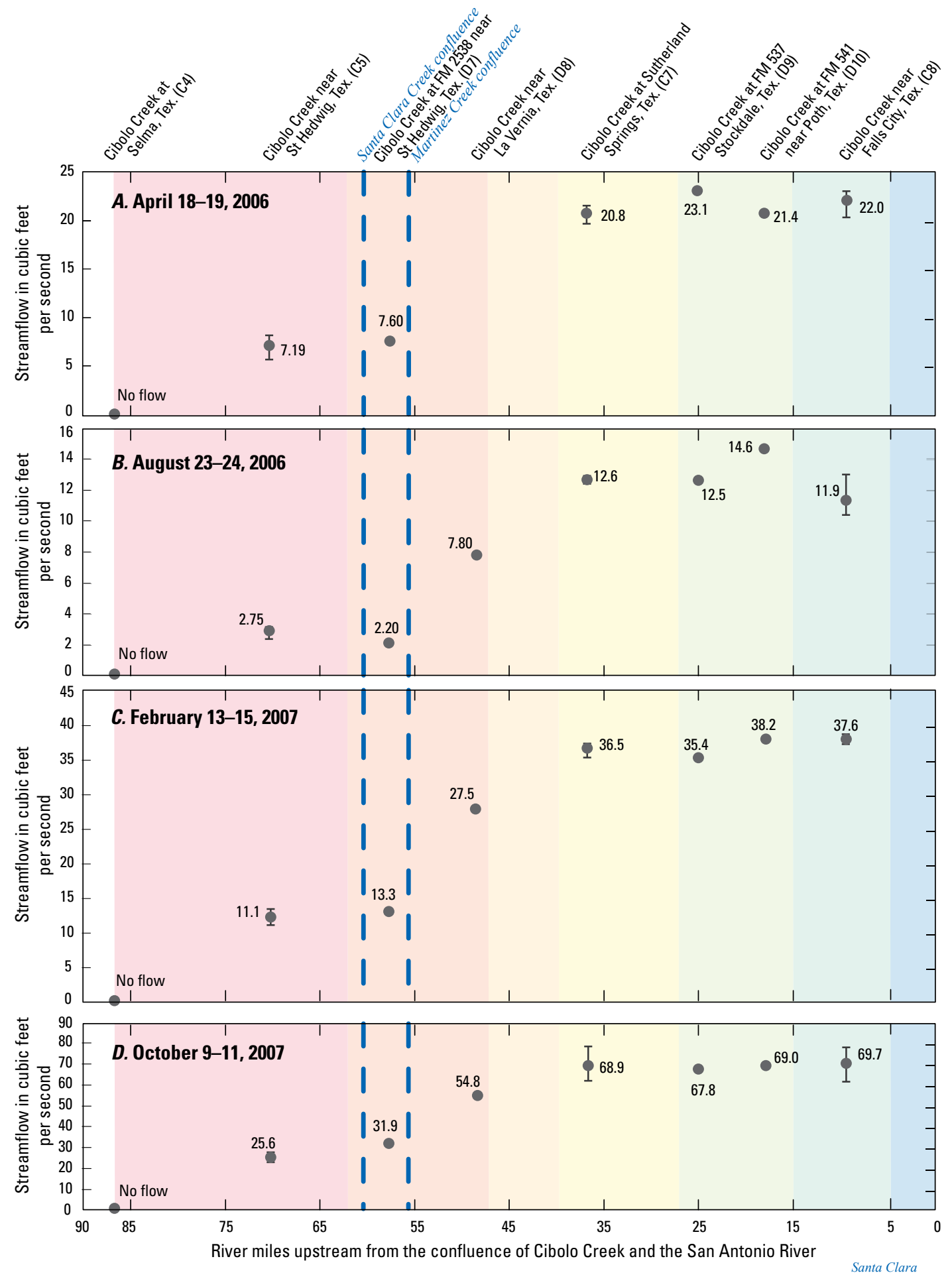

EXPLANATION

Water-budget zone boundary

Zone 1

Zone 2

Zone 3

Zone 4

Zone 5

Zone 6

Zone 7

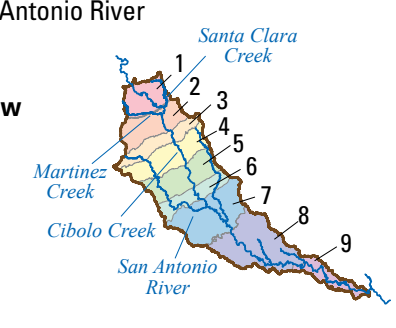

Figure 5. Discrete streamflow measurements made along the main channel of the Cibolo Creek during four synoptic surveys: A, April 18-19, 2006, B, August 23-24, 2006, C, February 13-15, 2007, and D, October 9-11, 2007. 
confluence of the San Antonio River with Cibolo Creek, and an increase across zone 9 (fig. 2), which includes the outcrop of the Lissie Formation.

Most of the gain in Cibolo Creek occurred in the reaches overlying zones 2, 3, and 4 (fig. 5), which includes the outcrops of the Wilcox Group, Carrizo Sand, and Queen City Sand (fig. 2).

For the 11 reaches of the San Antonio River and 7 reaches of Cibolo Creek, streamflow gains or losses were computed for the four synoptic streamflow measurement survey periods (tables 9-11). It is not known whether or not there were actual diversions based on the active surface-water rights (table 4) during the short periods of the synoptic streamflow measurement surveys. Therefore, permitted diversion amounts from active surface-water rights were not included in the analysis of streamflow gains and losses during the synoptic streamflow measurement surveys.

On the main stem of the lower San Antonio River, the synoptic streamflow measurement survey data showed generally increasing streamflow in the downstream direction from site $\mathrm{C} 1$ to site $\mathrm{C} 11$ (table 9). Measured tributary inflows from Cibolo Creek and smaller tributaries composed at least 24 percent of the gain in San Antonio River streamflow in the first three synoptic streamflow measurement surveys. In the October 2007 synoptic streamflow measurement survey, only 19 percent of the overall gain was from measured tributary inflow.

Along the main stem of the lower San Antonio River, verifiable gains larger than the potential measurement error were estimated in two of the four synoptic streamflow measurement surveys (fig. 6, $A$ and $C$ ). These gaining reaches occurred in the two most downstream reaches of the San Antonio River between sites C10 at Goliad and D20 near Fannin and between sites D20 near Fannin and C11 near McFaddin. During the April survey, there was a verifiable gain estimated as $30.9 \mathrm{ft}^{3} / \mathrm{s}$ between site C10 and site D20. During the February 2007 synoptic streamflow measurement survey, there was a verifiable gain estimated as $61.0 \mathrm{ft}^{3} / \mathrm{s}$ between sites D20 and C11.

Except for the February synoptic streamflow measurement survey, most of the overall gain in the main stem of the lower San Antonio River that was not accounted for by measured tributary inflow or discharges was measured in the reach between site C10 and site C11 (table 10). During February 2007 (the wetter year), the water-level altitudes in wells were just beginning to rise near site $\mathrm{C} 10$, and there was a gain of $38.0 \mathrm{ft}^{3} / \mathrm{s}$ in streamflow between site $\mathrm{C} 10$ and site C11 (table 10); however, this was not larger than the range of potential measurement error. By October 2007, after substantial rainfall across the study area, water-level altitudes had responded and there was an estimated gain of $207 \mathrm{ft}^{3} / \mathrm{s}$ between site $\mathrm{C} 10$ and site $\mathrm{C} 11$ measured during the synoptic streamflow measurement survey (table 10). While also not verifiable, this gain represented 46 percent of the overall gain in streamflow for the reach between sites $\mathrm{C} 1$ and $\mathrm{C} 11$.

At the most upstream site on Cibolo Creek (site C4), no flow was observed during any of the synoptic streamflow measurement surveys (fig. 5). The Cibolo Creek Municipal Authority plant (site WW3; table 2) discharges to Cibolo Creek upstream from site C5 near St. Hedwig on Cibolo Creek (fig. 1, table 1), where streamflow ranged from $2.37-26.3 \mathrm{ft}^{3} / \mathrm{s}$ during the four synoptic streamflow measurement surveys (fig. 5, table 11). Martinez Creek was the only tributary to Cibolo Creek that was flowing during the synoptic streamflow measurement surveys. During base-flow conditions, streamflow measured at site C6 on Martinez Creek was composed mostly of discharge from the Salitrillo, Upper Martinez I, and Martinez II wastewater-treatment facilities (fig. 4, table 2). Computed discharge at site 66 ranged from 5.73-14.0 ft $3 / \mathrm{s}$ during the synoptic streamflow measurement surveys (no data were collected during the February 13-15, 2007 survey). Martinez Creek discharges into Cibolo Creek downstream from site C5 (fig. 1, table 1).

There were verifiable gains in streamflow in Cibolo Creek, between La Vernia, Tex. (site D8) and the town of Sutherland Springs, Tex. (site C7), during all four surveys, estimated at between $4.8-14 \mathrm{ft}^{3} / \mathrm{s}$ (fig. 6 , table 11). Added to this gain would be any diversions that might have been made to satisfy permitted amounts. During the April 2006, February 2007, and October 2007 synoptic streamflow measurement surveys, there were also verifiable gains in reaches upstream from site D8 (fig. 6) where Cibolo Creek crosses over the outcrop of the Wilcox Group (fig. 2). Much of the rainfall prior to the October 2007 survey occurred south of these gaining reaches (National Climatic Data Center, 2011). In August 2006, after a long period of minimal rainfall, while Cibolo Creek was still gaining streamflow between La Vernia and Sutherland Springs (smallest amount of streamflow gain during the four surveys), there were verifiable losses in streamflow on Cibolo Creek from sites C4 to C6 and sites D10 to $\mathrm{C} 8$. 
$\boldsymbol{A}$

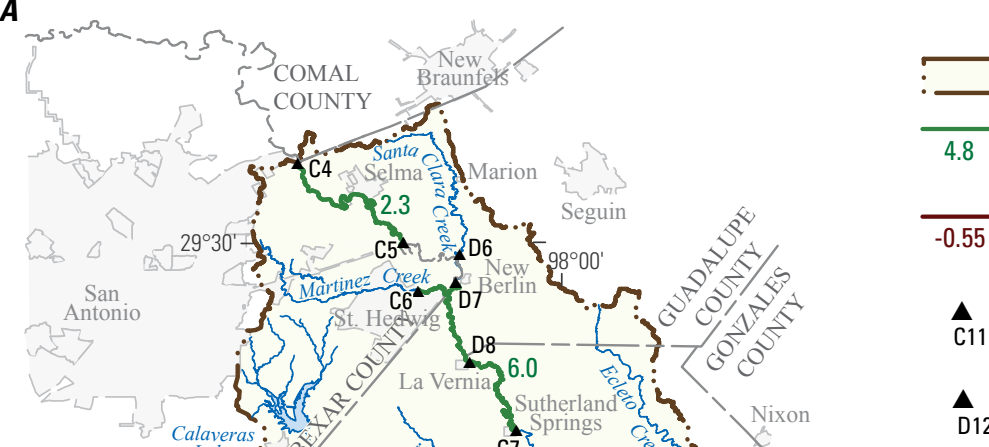

B
EXPLANATION

Lower San Antonio River watershed

Verifiable gain between stations with estimated amount in cubic feet per second

Verifiable loss between stations with estimated amount in cubic feet per second

U.S. Geological Survey continuous streamflowgaging station and site identifier-See table 1

Discrete streamflow measurement location and site identifier-See table 1

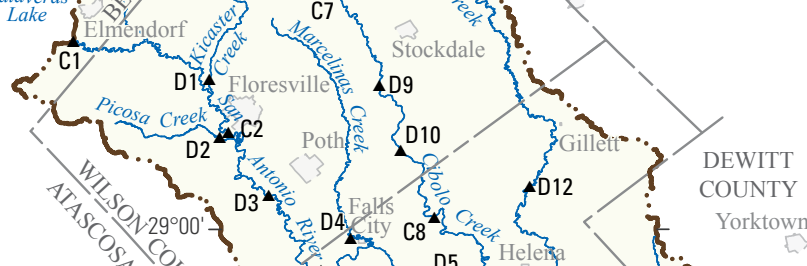

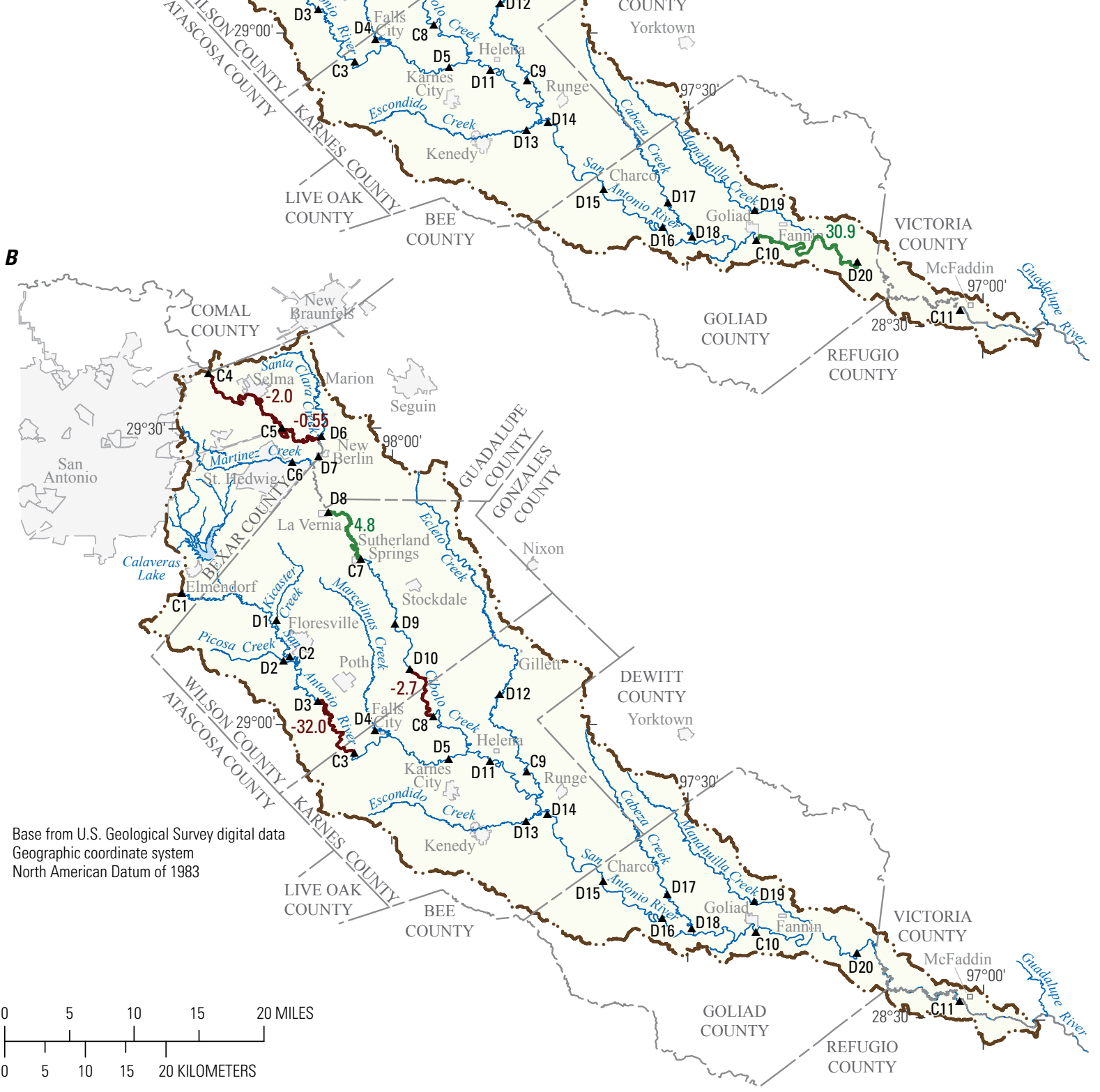

Base from U.S. Geological Survey digital data Geographic coordinate system North American Datum of 1983

Figure 6. Verifiable streamflow gains and losses during four synoptic surveys in lower San Antonio River watershed: A, April 18-19, 2006; $B$, August 23-24, 2006; $C$, February 13-15, 2007; and D, 0ctober 9-11, 2007, south-central Texas. 
C$$
\text { }
$$

EXPLANATION

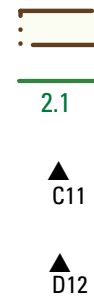

Lower San Antonio River watershed

Verifiable gain between stations with estimated amount in cubic feet per second

U.S. Geological Survey continuous streamflowgaging station and site identifier-See table 1

Discrete streamflow measurement location and site identifier-See table 1

D

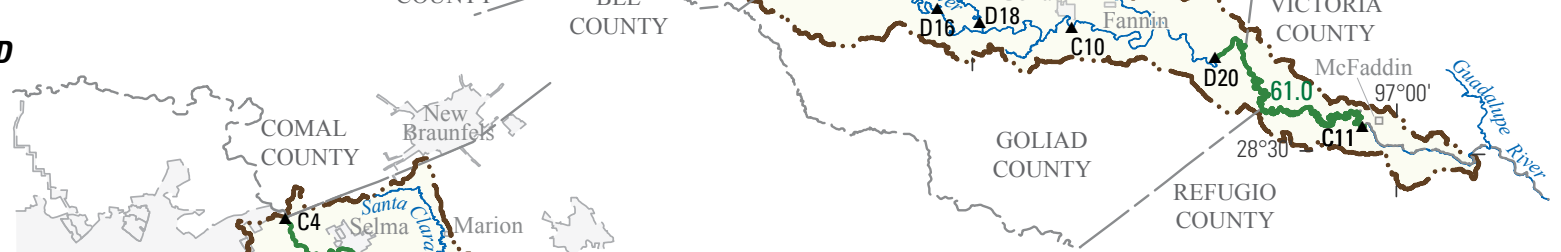

Base from U.S. Geological Survey digital data Geographic coordinate system North American Datum of 1983
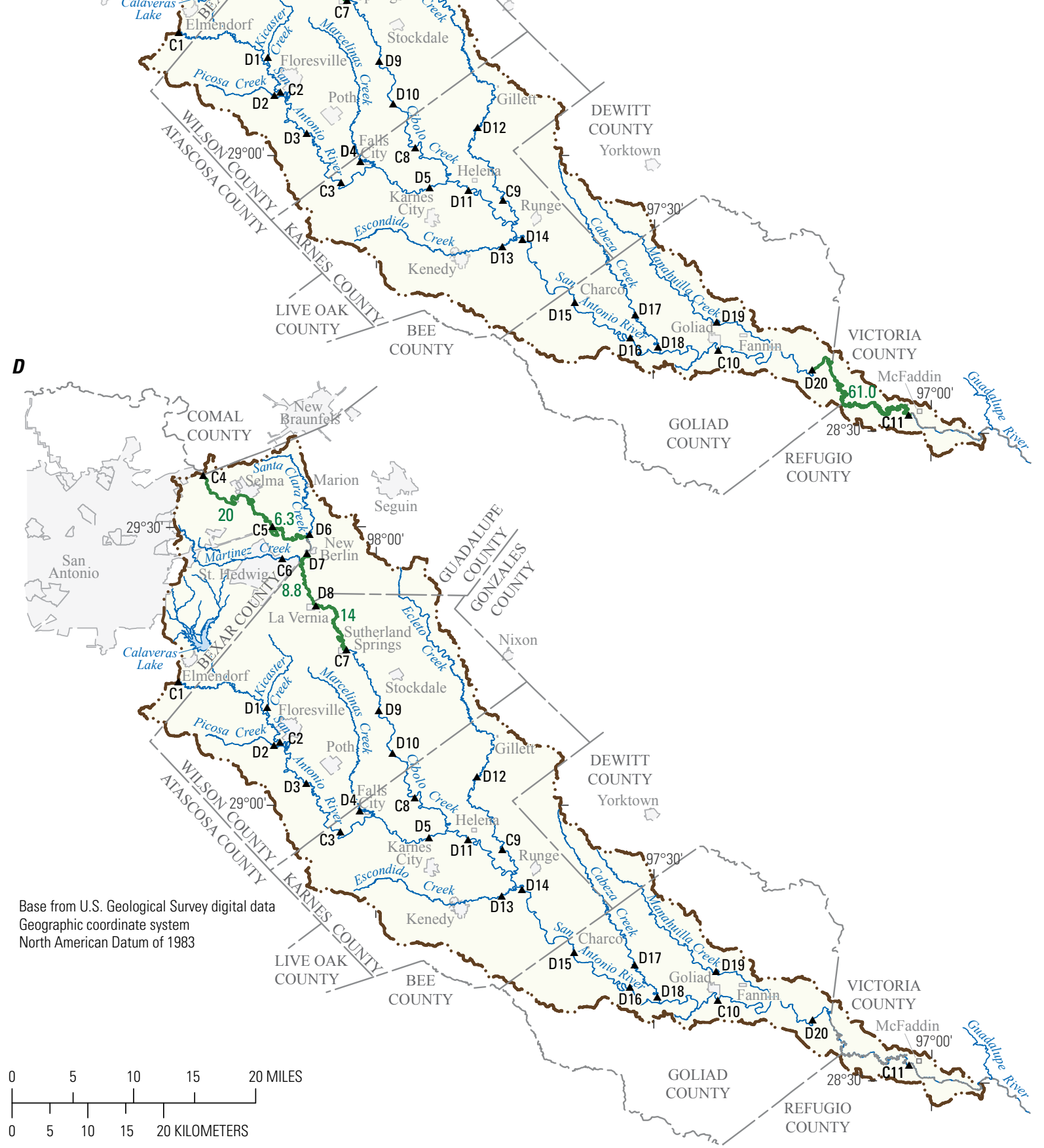

Figure 6. - Continued 


\section{Summary}

The U.S. Geological Survey (USGS), in cooperation with the San Antonio River Authority, the Evergreen Underground Water Conservation District, and the Goliad County Groundwater Conservation District, investigated streamflow gains and losses during 2006-10 in the lower San Antonio River watershed in south-central Texas. Streamflow gains and losses were estimated using 2006-10 continuous streamflow records from 11 continuous streamflow-gaging stations, and discrete streamflow measurements made at as many as 20 locations on the San Antonio River and selected tributaries during four synoptic surveys during 2006-7 (19 and 20 measurement sites during April and August 2006, respectively, and 15 and 20 measurement sites during February and October 2007, respectively). The lower San Antonio River and lower Cibolo Creek generally gain streamflow in the downstream direction. From the continuous streamflow records, the greatest streamflow gain on the lower San Antonio River occurred in the reach from Falls City to Goliad, Tex. The greatest streamflow gain on Cibolo Creek during 2006-10 occurred in the reach from near Saint Hedwig, Tex., to Sutherland Springs, Tex. The San Antonio River between Floresville, Tex., and Falls City, Tex., was the only reach that had an estimated streamflow loss during 2006-10.

During all four synoptic streamflow measurement surveys, the only substantially flowing tributary reach to the main stem of the lower San Antonio River was Cibolo Creek. Tributaries of the main channel of the San Antonio River, with the exception of Cibolo Creek, were not flowing or only minimally flowing during the 2006 and 2007 synoptic streamflow measurement surveys. Most of the gain in the main channel of the lower San Antonio River occurred gradually except for an abrupt increase at the confluence of the San Antonio River with Cibolo Creek. Most of the gain in Cibolo Creek flow occurred in the reaches overlying the outcrops of the Wilcox group, Carrizo Sand, and Queen City Sand.

On the main stem of the lower San Antonio River, the synoptic streamflow measurement survey data showed generally increasing streamflow in the downstream direction from near Falls City and to near McFaddin. Measured tributary inflows from Cibolo Creek and smaller tributaries composed at least 24 percent of the gain in San Antonio River streamflow in the first three synoptic streamflow measurement surveys. In the October 2007 synoptic streamflow measurement survey, only 19 percent of the overall gain was from measured tributary inflow.

Along the main stem of the lower San Antonio River, verifiable gains larger than the potential measurement error were estimated in two of the four synoptic streamflow measurement surveys. These gaining reaches occurred in the two most downstream reaches of the San Antonio River between Goliad and Farm Road (FM) 2506 near Fannin, Tex., and between FM 2506 near Fannin to near McFaddin. During the April 2006 survey, there was a verifiable gain estimated as $30.9 \mathrm{ft}^{3} / \mathrm{s}$ between Goliad and FM 2506 near Fannin. During the February 2007 synoptic streamflow measurement survey, there was a verifiable gain estimated as $61.0 \mathrm{ft}^{3} / \mathrm{s}$ between FM 2506 near Fannin to near McFaddin.

There were verifiable gains in streamflow in Cibolo Creek, between La Vernia, Tex., and the town of Sutherland Springs during all four surveys, estimated at between 4.8 and $14 \mathrm{ft}^{3} / \mathrm{s}$. Added to this gain would be any diversions that might have been made to satisfy permitted amounts. During the April 2006, February 2007, and October 2007 synoptic streamflow measurement surveys, there were also verifiable gains in reaches upstream from measurement site on Cibolo Creek at FM 775 near La Vernia where Cibolo Creek crosses over the outcrop of the Wilcox Group. In August 2006, after a long period of minimal rainfall, while Cibolo Creek was still gaining streamflow between La Vernia and Sutherland Springs, there were verifiable losses in streamflow on Cibolo Creek between Cibolo Creek at Selma, Tex., and Martinez Creek near Saint Hedwig, Tex., and between FM 541 near Poth, Tex., and near Falls City, Tex.

\section{References}

Aronow, S., Brown, T.E., Brewton, J.L., Eargle, D.H., and Barnes, V.E., 1987, Geologic atlas of Texas, GA0005 Beeville-Bay City sheet: Austin, The University of Texas, Bureau of Economic Geology, 4 p., 1 sheet.

Brown, T.E., Waechter, N.B., and Barnes, V.E., 1983, Geologic atlas of Texas, GA0029 San Antonio sheet: Austin, The University of Texas, Bureau of Economic Geology, 8 p., 1 sheet.

Brown, T.E., Waechter, N.B., Owens, F., Howeth, I., and Barnes, V.E., 1976, Geologic atlas of Texas, GA0011 Crystal-City Eagle Pass sheet: Austin, The University of Texas, Bureau of Economic Geology, 6 p., 1 sheet.

Cawthon, T., 2008, Channel change on the San Antonio River: Texas Water Development Board, Project 0604830638, accessed June 21, 2011, at http://www.twdb. state.tx.us/RWPG/rpgm_rpts/0604830638_channelchange. pdf.

Cunningham, W.L., and Schalk, C.W., 2011, Groundwater technical procedures of the U.S. Geological Survey: U.S. Geological Survey Techniques and Methods 1-A1, 151 p., accessed September 14, 2011, at http://pubs.usgs.gov/ tm/1a1/pdf/tm1-a1.pdf.

Engel, F.L., 2008, Geomorphic classification of the lower San Antonio River, Texas: Texas Water Development Board, Project 0604830637, accessed July 7, 2011, at http://www.twdb.state.tx.us/RWPG/rpgm_rpts/0604830637 LowerSanAntonioRiver.pdf. 
Kasmarek, M.C., and Robinson, J.L., 2004, Hydrogeology and simulation of ground-water flow and land-surface subsidence in the northern part of the Gulf Coast aquifer system, Texas: U.S. Geological Survey Scientific Investigations Report 2004-5102, 111 p. (Also available at http:// pubs.usgs.gov/sir/2004/5102/pdf/sir2004-5102.pdf.)

Kennedy, E.J., 1984, Discharge ratings at gaging stations: U.S. Geological Survey Techniques of Water-Resources Investigations, book 3, chap. A10, 59 p. (Also available at http://pubs.usgs.gov/twri/twri3-a10/.)

Larkin, T.J., and Bomar, G.W., 1983, Climatic atlas of Texas: LP-192. Texas Department of Water Resources, 157 p., accessed on January 26, 2012, at http://www.twdb.state. tx.us/publications/reports/limited_printing/doc/LP192.pdf.

Lizárraga, J.S., and Ockerman, D.J., 2010, Simulation of streamflow, evapotranspiration, and groundwater recharge in the lower San Antonio River watershed, south-central Texas, 2000-2007: U.S. Geological Survey Open-File Report 2010-5027, 41 p.

National Climatic Data Center, 2011, Weather and climate events - Data and products: National Climatic Data Center, accessed July 10, 2011, at http://www.ncdc.noaa.gov/oa/ ncdc.html.

Natural Resources Conservation Service, 2009, WinTR-55, Version 1.00.09: accessed June 1, 2011, at http://www. nrcs.usda.gov/wps/portal/nrcs/detailfull/national/water/ manage/?\&cid=stelprdb1042901.

Novak, C.E., 1985, WRD data reports preparation guide: U.S. Geological Survey Open-File Report 85-480, 199 p.

Oberg, K.A., Morlock, S.E., and Caldwell, W.S., 2005, Quality-assurance plan for discharge measurements using acoustic Doppler current profilers: U.S. Geological Survey Scientific Investigations Report 2005-5183, 35 p.

Ockerman, D.J., and McNamara, K.C., 2003, Simulation of streamflow and estimation of streamflow constituent loads in the San Antonio River watershed, Bexar County, Texas, 1997-2001: U.S. Geological Survey Water-Resources Investigations Report 03-4030, $37 \mathrm{p}$.

Proctor, C.V., Jr., Brown, T.E., Waechter, N.B., Aronow, S., and Barnes, V.E., 1974, Geologic atlas of Texas, GA0030 Seguin sheet: Austin, The University of Texas, Bureau of Economic Geology, 6 p., 1 sheet.

Rantz, S.E., and others, 1982, Measurement and computation of streamflow-Volume 1. Measurement of stage and discharge: U.S. Geological Survey Water-Supply Paper 2175, chap. 5, 79-183 p.

Ryder, P.D., 1996, Ground water atlas of the United StatesSegment 4, Oklahoma, Texas: U.S. Geological Survey Hydrologic Investigations Atlas 730-E, $30 \mathrm{p}$.
San Antonio River Authority, 2008, Basin summary report 2008: San Antonio River Authority, accessed July 19, 2011, at http://www.sara-tx.org/public_resources/library/ documents/water_quality_monitoring/2008SummaryReport. pdf.

Sauer, V.B., and Meyer, R.W., 1992, Determination of error in individual discharge measurements: U.S. Geological Survey Open-File Report 92-144, 21 p., accessed July 5, 2011, at http://pubs.usgs.gov/of/1992/ofr92-144/.

Slade, R.M., Jr., Bentley, J.T., and Michaud, Dana, 2002, Results of streamflow gain-loss studies in Texas, with emphasis on gains from and losses to major and minor aquifers: U.S. Geological Survey Open-File Report 02-068, 136 p. (Also available at http://pubs.usgs.gov/of/2002/ ofr02-068/.)

Texas Commission on Environmental Quality, 2010, Water rights database and related files: Texas Commission on Environmental Quality, accessed December 20, 2010, at http://www.tceq.state.tx.us/permitting/water_supply/ water_rights/wr_databases.html.

Texas Commission on Environmental Quality, 2011a, Site layers, surface water rights diversion points: Texas Commission on Environmental Quality, accessed June 15, 2011, at http://www.tceq.state.tx.us/gis/sites.html.

Texas Commission on Environmental Quality, 2011b, Site layers, permitted wastewater outfalls: Texas Commission on Environmental Quality, accessed February 1, 2011, at http://www.tceq.state.tx.us/gis/sites.html.

Texas Instream Flow Program and San Antonio River Authority, 2009, Instream flow study of the lower San Antonio River and lower Cibolo Creek, draft study design: Texas Instream Flow Program and San Antonio River Authority, accessed June 21, 2011, at http://www.twdb.state.tx.us/ instreamflows/pdfs/4thMeetingSanAnt/LSAR_Draft_ Study_Design_June\%202009.pdf.

Townsend, R.L., 1986, Cancellation of water rights in Texas: Use it or lose it: St. Mary's Law Journal, v. 17, p. 1217-1240.

Turco, M.J., East, J.W., and Milburn, M.S., 2007, Base flow (1966-2005) and streamflow gain and loss (2006) of the Brazos River, McLennan County to Fort Bend County, Texas: U.S. Geological Survey Scientific Investigations Report 2007-5286, 27 p.

Turnipseed, D.P., and Sauer, V.B., 2010, Discharge measurements at gaging stations: U.S. Geological Survey Techniques and Methods book 3, chap. A8, 87 p., accessed October 20, 2011, at http://pubs.usgs.gov/tm/ $\operatorname{tm} 3 \mathrm{a} 8 /$. 
U.S. Environmental Protection Agency, 2010, Clean watersheds needs survey (CWNS)_CWNS 2008 data: U.S.

Environmental Protection Agency, Water-Science and Technology [database], accessed March 6, 2012, at http://water.epa.gov/scitech/datait/databases/cwns/ 2008reportdata.cfm.

U.S. Geological Survey, 1999, The quality of our Nation's waters-Nutrients and pesticides: U.S. Geological Survey Circular 1225, 82 p., accessed March 2, 2012, at http://pubs. usgs.gov/circ/circ1225/pdf/front.pdf.

U.S. Geological Survey, 2011a, USGS water data for Texas: National Water Information System: Web interface, accessed January 25, 2011, at http:/waterdata.usgs.gov/tx/ nwis/nwis
U.S. Geological Survey, 2011b, Annual water data reports: U.S. Geological Survey, accessed June 13, 2011, at http://wdr.water.usgs.gov.

Xylem Analytics, 2012, Sontek argonaut acoustic Doppler velocity meter and flowtracker principles of operation: accessed March 1, 2012, at http://www.xylemanalytics. $\mathrm{com} /$.

Young, S.C., Budge, Trevor, Knox, P.R., Kalbouss, Robert, Baker, Ernie, Hamlin, Scott, Galloway, Bill, Deeds, Neil, 2010, Hydrostratigraphy of the Gulf Coast aquifer from the Brazos River to the Rio Grande: Texas Water Development Board, accessed December 1, 2010, at http://www.twdb. state.tx.us/RWPG/rpgm_rpts/0804830795_Gulf_coast hydrostratigraphy_wcover.pdf. 
Table 1. U.S. Geological Survey continuous and discrete measurement locations in the lower San Antonio River watershed, southcentral Texas, 2006-10.

[USGS, U.S. Geological Survey; mi² $^{2}$ square miles; FM, Farm Road; Hwy, Highway; --, not applicable; Tex., Texas]

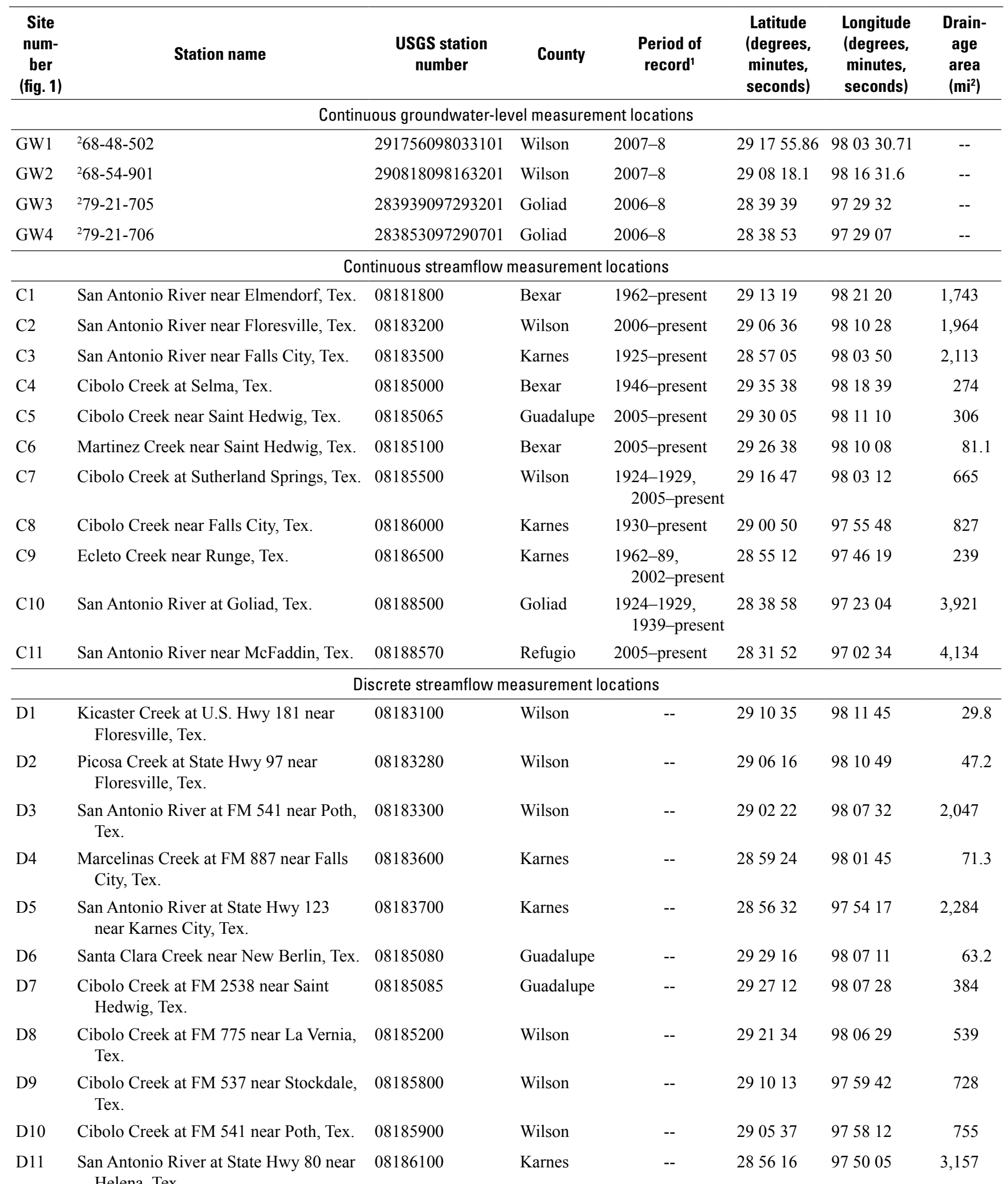


Table 1. U.S. Geological Survey continuous and discrete measurement locations in the lower San Antonio River watershed, southcentral Texas, 2006-10.-Continued

[USGS, U.S. Geological Survey; mi², square miles; FM, Farm Road; Hwy, Highway; --, not applicable; Tex., Texas]

\begin{tabular}{|c|c|c|c|c|c|c|c|}
\hline $\begin{array}{c}\text { Site } \\
\text { num- } \\
\text { ber } \\
\text { (fig. 1) }\end{array}$ & Station name & $\begin{array}{l}\text { USGS station } \\
\text { number }\end{array}$ & County & $\begin{array}{l}\text { Period of } \\
\text { record }^{1}\end{array}$ & $\begin{array}{c}\text { Latitude } \\
\text { (degrees, } \\
\text { minutes, } \\
\text { seconds) }\end{array}$ & $\begin{array}{l}\text { Longitude } \\
\text { (degrees, } \\
\text { minutes, } \\
\text { seconds) }\end{array}$ & $\begin{array}{l}\text { Drain- } \\
\text { age } \\
\text { area } \\
\left(\mathrm{mi}^{2}\right)\end{array}$ \\
\hline \multicolumn{8}{|c|}{ Discrete streamflow measurement locations-Continued } \\
\hline D12 & $\begin{array}{l}\text { Ecleto Creek at FM } 627 \text { near Gillett, } \\
\text { Tex. }\end{array}$ & 08186450 & Karnes & -- & 290304 & 974906 & 134 \\
\hline D14 & $\begin{array}{l}\text { San Antonio River at State Highway } 72 \\
\text { near Runge, Tex. }\end{array}$ & 08188060 & Karnes & -- & 285055 & 974414 & 3,570 \\
\hline D15 & San Antonio River near Charco, Tex. & 08188200 & Goliad & -- & 984407 & 973835 & 3,688 \\
\hline D16 & $\begin{array}{l}\text { San Antonio River at Riverdale Road } \\
\text { near Goliad, Tex. }\end{array}$ & 08188300 & Goliad & -- & 284019 & 973235 & 3,774 \\
\hline D18 & $\begin{array}{l}\text { Cabeza Creek at FM } 2043 \text { near Goliad, } \\
\text { Tex. }\end{array}$ & 08188350 & Goliad & -- & 283918 & 972936 & 76.0 \\
\hline D19 & $\begin{array}{l}\text { Manahuilla Creek at U.S. Hwy } 183 \text { near } \\
\text { Goliad, Tex. }\end{array}$ & 08188525 & Goliad & -- & 284204 & 972316 & 89.4 \\
\hline D20 & $\begin{array}{l}\text { San Antonio River at FM } 2506 \text { near } \\
\text { Fannin, Tex. }\end{array}$ & 08188550 & Goliad & -- & 283647 & 971251 & 4,060 \\
\hline
\end{tabular}

aPresent indicates station was active in water year 2011.

${ }^{\mathrm{b}}$ State well number. 
Table 2. Permitted wastewater discharges included in gain and loss estimations during 2006-10 in the lower San Antonio River watershed, south-central Texas.

[Mgal/d, million gallons per day; $\mathrm{ft}^{3} / \mathrm{sec}$, cubic feet per second; WW, wastewater]

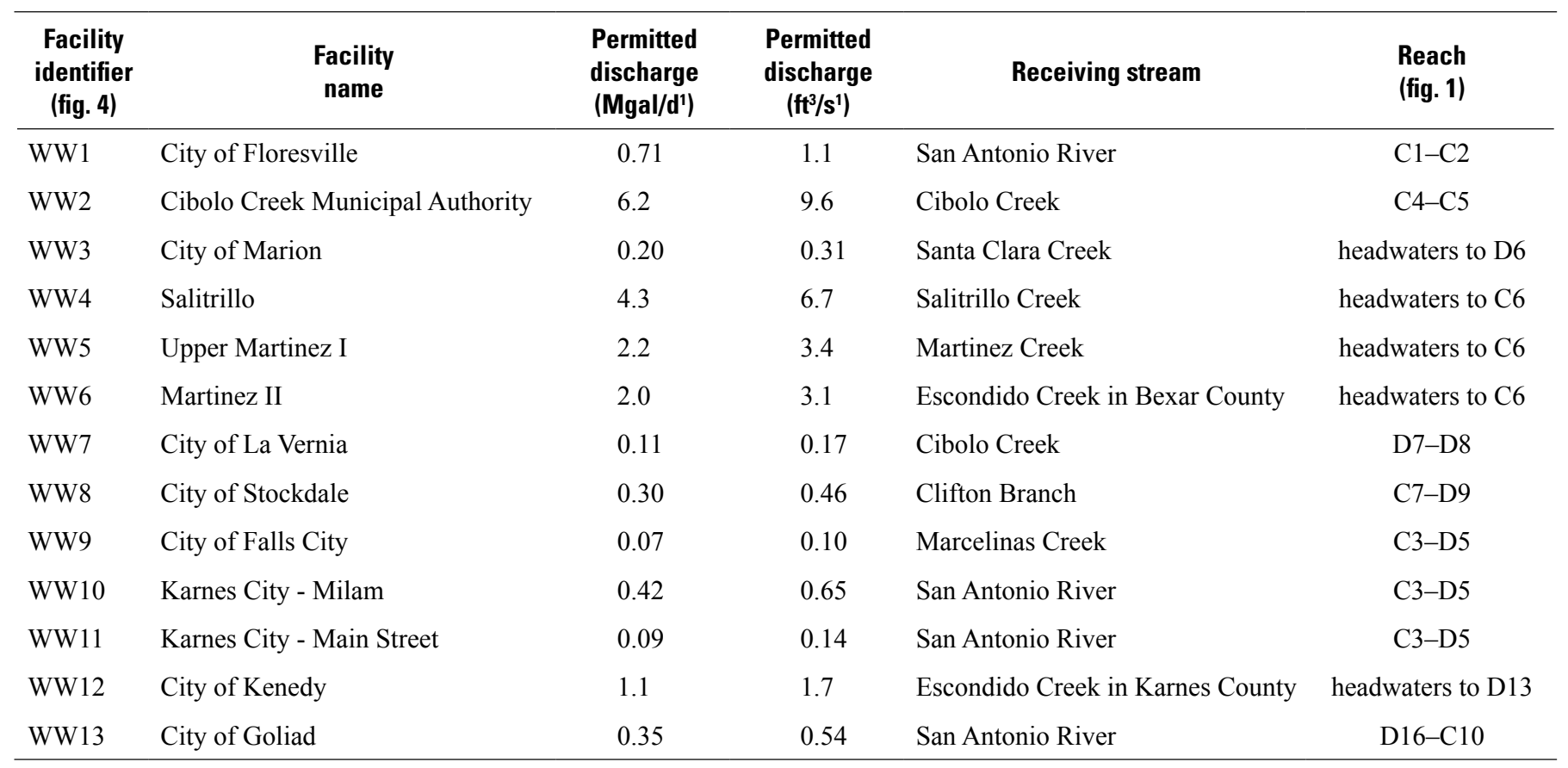

${ }^{1}$ Permitted discharge amount for the Cibolo Creek Municipal Authority from Clint Ellis, Cibolo Creek Municipal Authority, oral comm. (2012) and from U.S. Environmental Protection Agency (2010) for all other facilities.

Table 3. Annual rainfall, in inches, measured at three National Weather Service stations in or near the lower San Antonio River watershed, south-central Texas, 1960-2010.

\begin{tabular}{|c|c|c|c|}
\hline & \multicolumn{3}{|c|}{ National Weather Service station name and number ${ }^{1}$} \\
\hline 1960-2005 maximum & 52.3 & ${ }^{2} 54.4$ & ${ }^{3} 59.5$ \\
\hline 1960-2005 mean & 31.8 & ${ }^{2} 30.4$ & ${ }^{3} 38.3$ \\
\hline 2007 & 47.3 & 48.9 & 51.8 \\
\hline 2008 & 13.8 & 13.4 & 22.6 \\
\hline 2009 & 30.7 & 29.7 & 36.0 \\
\hline 2010 & 37.4 & 35.8 & 41.4 \\
\hline
\end{tabular}

${ }^{1}$ Station data accessed from National Climatic Data Center (2011).

${ }^{2}$ Annual precipitation unavailable 1982, 1984, 1986-91, and 2003.

${ }^{3}$ Annual precipitation unavailable $1986-88$. 
Table 4. Active surface-water rights (2010) with diversion amounts used for gain or loss estimates during 2006-10 in lower San Antonio River watershed, south-central Texas.

[ $\mathrm{ft}^{3} / \mathrm{s}$, cubic feet per second]

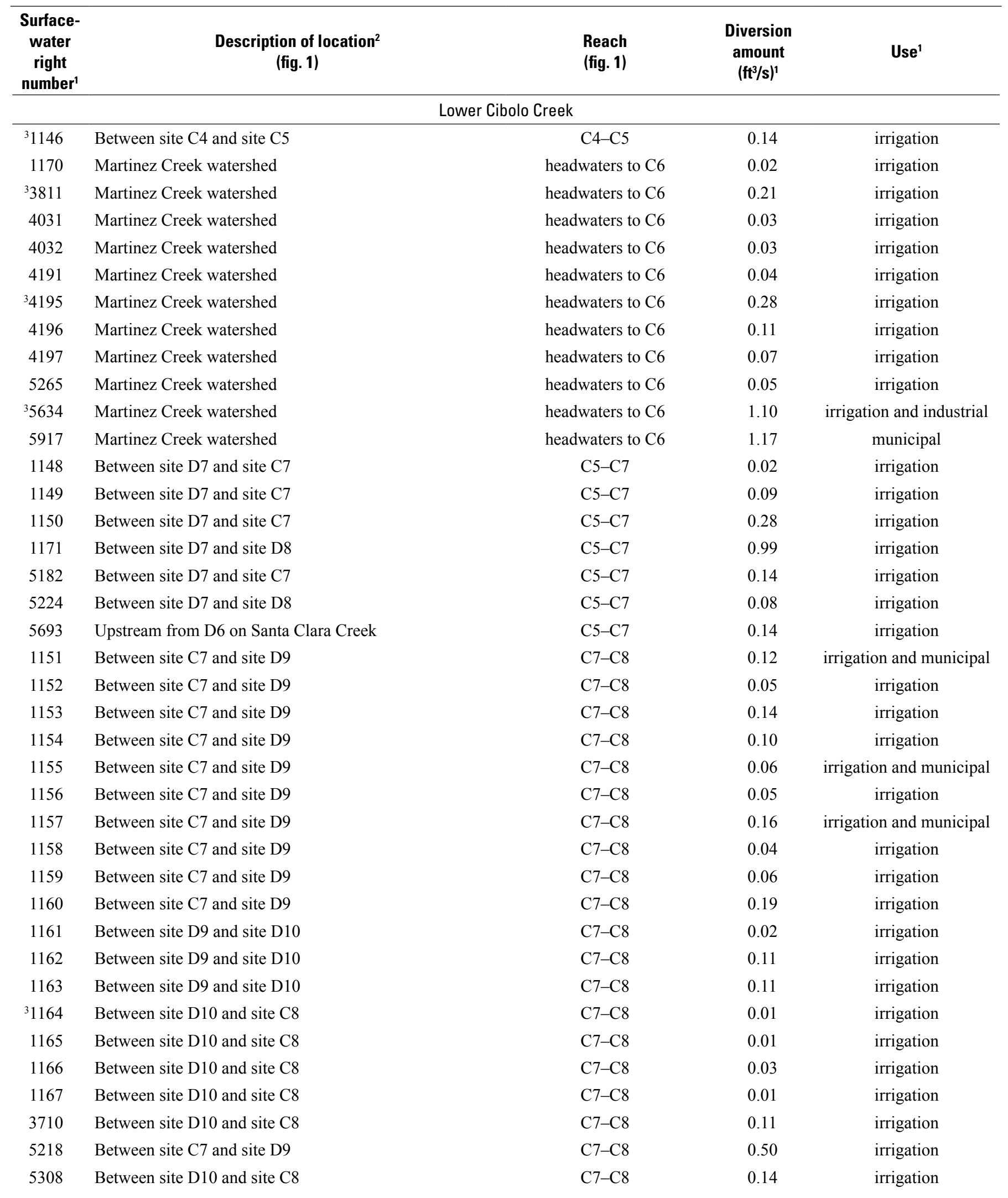


Table 4. Active surface-water rights (2010) with diversion amounts used for gain or loss estimates during 2006-10 in lower San Antonio River watershed, south-central Texas.-Continued

$\left[\mathrm{ft}^{3} / \mathrm{s}\right.$, cubic feet per second]

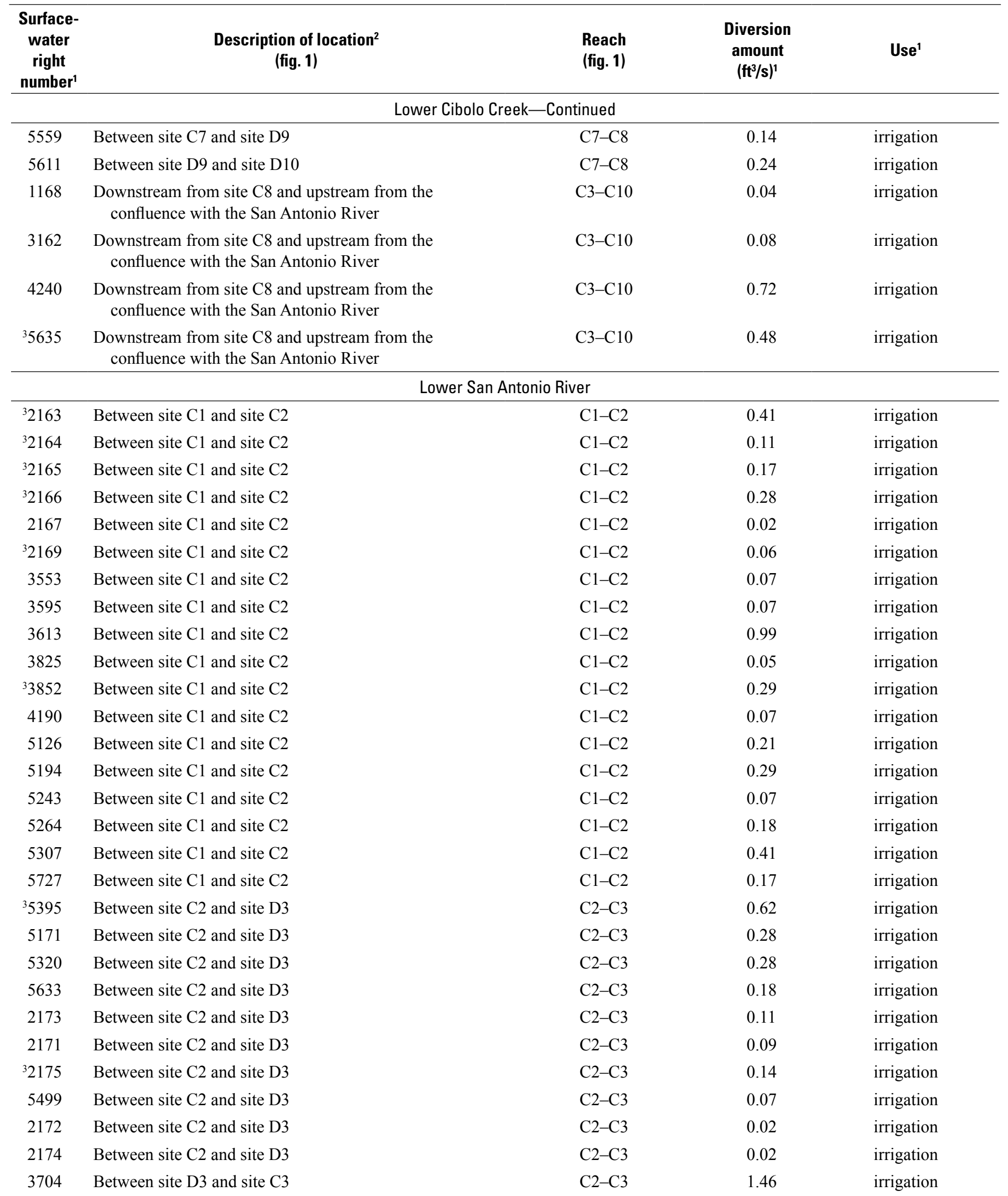


Table 4. Active surface-water rights (2010) with diversion amounts used for gain or loss estimates during 2006-10 in lower San Antonio River watershed, south-central Texas.-Continued

[ $\mathrm{ft}^{3} / \mathrm{s}$, cubic feet per second]

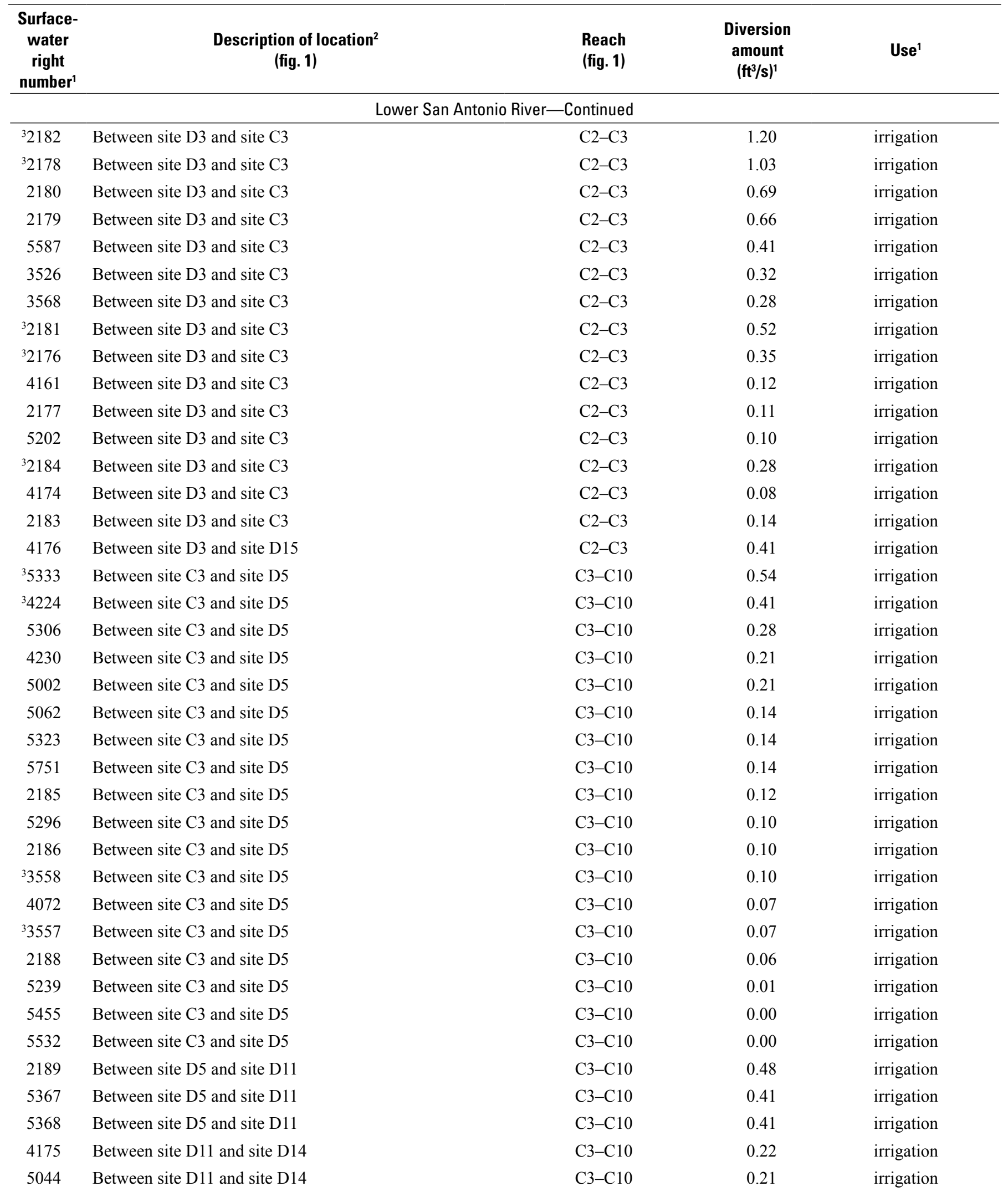


Table 4. Active surface-water rights (2010) with diversion amounts used for gain or loss estimates during 2006-10 in lower San Antonio River watershed, south-central Texas.-Continued

$\left[\mathrm{ft}^{3} / \mathrm{s}\right.$, cubic feet per second]

\begin{tabular}{|c|c|c|c|c|}
\hline $\begin{array}{c}\text { Surface- } \\
\text { water } \\
\text { right } \\
\text { number }^{1}\end{array}$ & $\begin{array}{c}\text { Description of location' } \\
\text { (fig. 1) }\end{array}$ & $\begin{array}{l}\text { Reach } \\
\text { (fig. 1) }\end{array}$ & $\begin{array}{c}\text { Diversion } \\
\text { amount } \\
\left(\mathrm{ft}^{3} / \mathrm{s}\right)^{1}\end{array}$ & Use $^{1}$ \\
\hline 2190 & Between site D11 and site D14 & $\mathrm{C} 3-\mathrm{C} 10$ & 0.14 & irrigation \\
\hline 3517 & Between site D11 and site D14 & $\mathrm{C} 3-\mathrm{C} 10$ & 0.11 & irrigation \\
\hline 5043 & Between site D14 and site D15 & $\mathrm{C} 3-\mathrm{C} 10$ & 0.21 & irrigation \\
\hline 2192 & Between site D14 and site D15 & $\mathrm{C} 3-\mathrm{C} 10$ & 0.19 & irrigation \\
\hline 2194 & Between site D15 and site D16 & $\mathrm{C} 3-\mathrm{C} 10$ & 1.41 & irrigation \\
\hline 2195 & Between site D15 and site D16 & $\mathrm{C} 3-\mathrm{C} 10$ & 0.57 & irrigation \\
\hline 2196 & Between site D15 and site D16 & $\mathrm{C} 3-\mathrm{C} 10$ & 0.46 & irrigation \\
\hline 2198 & Between site D16 and site $\mathrm{C} 10$ & $\mathrm{C} 3-\mathrm{C} 10$ & 0.46 & irrigation \\
\hline 5220 & Between site D16 and site C10 & $\mathrm{C} 3-\mathrm{C} 10$ & 0.46 & irrigation \\
\hline 2199 & Between site D16 and site C10 & $\mathrm{C} 3-\mathrm{C} 10$ & 0.45 & irrigation \\
\hline 5478 & Between site D16 and site C10 & $\mathrm{C} 3-\mathrm{C} 10$ & 0.41 & irrigation \\
\hline 5079 & Between site D16 and site C10 & $\mathrm{C} 3-\mathrm{C} 10$ & 0.16 & irrigation \\
\hline 2197 & Between site D16 and site C10 & $\mathrm{C} 3-\mathrm{C} 10$ & 0.12 & irrigation \\
\hline 5489 & Between site $\mathrm{C} 1$ and site $\mathrm{C} 2$ & downstream from $\mathrm{C} 10$ & 1.04 & other \\
\hline
\end{tabular}

${ }^{1}$ Surface-water right numbers, diversion amounts, and use were obtained from the Texas Commission on Environmental Quality (2010).

${ }^{2}$ Location obtained from the Texas Commission on Environmental Quality (2011a).

${ }^{3}$ More than one diversion amount listed for the same surface-water-permit number. The diversion amounts were summed. 
Table 5. Discrete streamflow measurements at 20 locations in the lower San Antonio River watershed, south-central Texas, $2006-7$.

[USGS, U.S. Geological Survey; $\mathrm{ft}^{\mathrm{t}} / \mathrm{s}$, cubic feet per second; italics indicate that the station is on a tributary; FM, Farm Road; Hwy, Highway; nm, not measured]

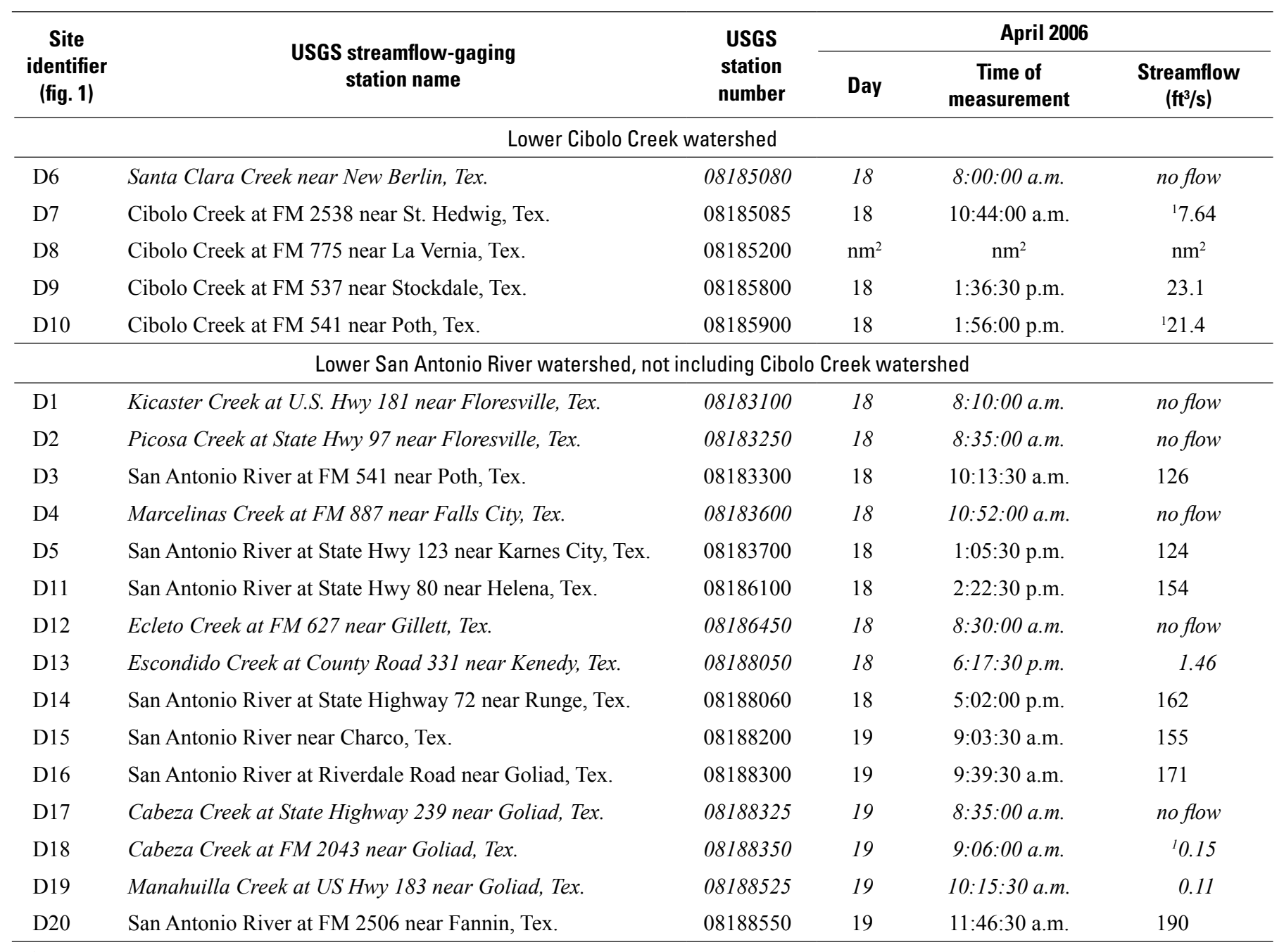

${ }^{1}$ Based on site conditions, two measurements were made and averaged within the hour of the listed time of measurement.

${ }^{2}$ Not measured because of bridge construction.

${ }^{3}$ Time is estimated. Visually inspected as dry (Brian Petri, U.S. Geological Survey, oral commun., 2011).

${ }^{4}$ Time is estimated (Brian Petri, U.S. Geological Survey, oral commun., 2011). 
Table 5. Discrete streamflow measurements at 20 locations in the lower San Antonio River watershed, south-central Texas, 2006-7.Continued

[USGS, U.S. Geological Survey; $\mathrm{ft}^{3} / \mathrm{s}$, cubic feet per second; italics indicate that the station is on a tributary; FM, Farm Road; Hwy, Highway; nm, not measured]

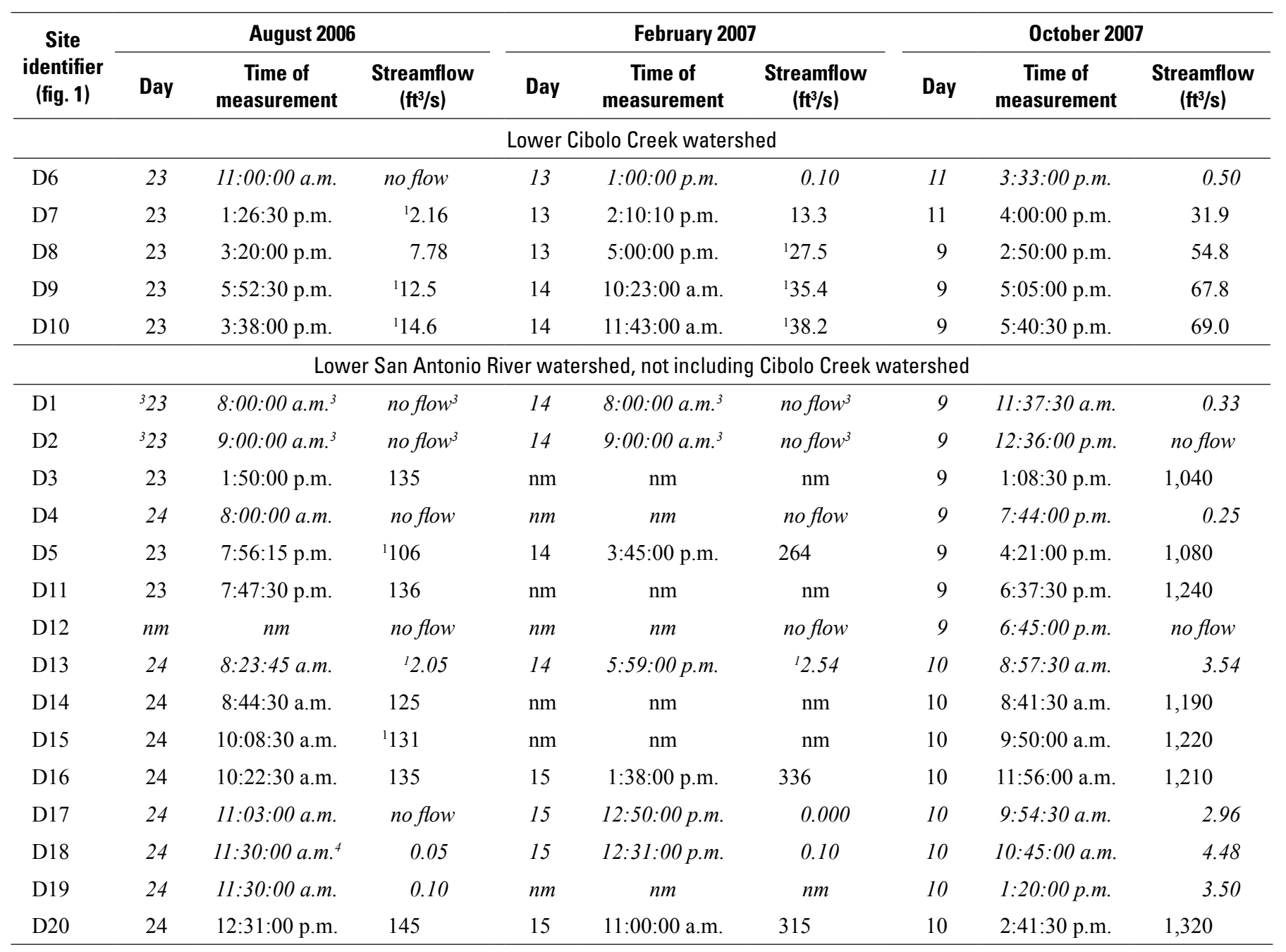


Table 6. Average daily discharge of treated wastewater, in cubic feet per second, during synoptic streamflow measurement surveys, lower San Antonio River watershed, south Texas, 2006-10.

$[--$, not available $]$

\begin{tabular}{|c|c|c|c|c|c|c|c|c|c|c|c|}
\hline $\begin{array}{l}\text { Facility } \\
\text { identi- } \\
\text { fier } \\
\text { (fig. 4) }\end{array}$ & $\begin{array}{l}\text { Facility name } \\
\text { (table 2) }\end{array}$ & 4/18/2006 & 4/19/2006 & 8/23/2006 & 8/24/2006 & 2/13/2007 & 2/14/2007 & 2/15/2007 & 10/9/2007 & 10/10/2007 & 10/11/2007 \\
\hline WW1 & City of Floresville ${ }^{1}$ & 0.853 & 0.853 & 0.890 & 0.889 & 0.878 & 0.879 & 0.876 & 0.933 & 0.933 & 0.93 \\
\hline WW2 & $\begin{array}{c}\text { Cibolo Creek } \\
\text { Municipal } \\
\text { Authority }^{2}\end{array}$ & 3.54 & 6.16 & 4.35 & 5.09 & 6.41 & 6.33 & 6.24 & 5.17 & 6.42 & 6.56 \\
\hline WW3 & City of Marion ${ }^{3}$ & 0.036 & 0.036 & 0.048 & 0.048 & 0.046 & 0.063 & 0.063 & 0.067 & 0.056 & 0.051 \\
\hline WW4 & Salitrillo ${ }^{4}$ & 4.82 & 5.13 & 4.71 & 4.67 & 5.56 & 5.45 & 3.17 & 5.49 & 5.46 & 5.38 \\
\hline WW5 & Upper Martinez I I & 2.30 & 2.15 & 2.21 & 2.09 & 2.42 & 2.49 & 2.21 & 2.70 & 2.59 & 2.52 \\
\hline WW6 & Martinez II ${ }^{4}$ & 1.84 & 1.89 & 1.80 & 1.94 & 1.92 & 1.73 & 2.11 & 1.85 & 1.67 & 1.72 \\
\hline WW7 & City of La Vernia ${ }^{4}$ & 0.125 & 0.129 & 0.133 & 0.139 & 0.148 & 0.125 & 0.146 & 0.156 & 0.154 & 0.16 \\
\hline WW8 & City of Stockdale & 0.152 & 0.152 & 0.152 & 0.152 & 0.183 & 0.152 & 0.152 & 0.152 & 0.141 & 0.152 \\
\hline WW9 & City of Falls City ${ }^{6}$ & no flow & no flow & no flow & no flow & no flow & no flow & no flow & no flow & no flow & no flow \\
\hline WW10 & $\begin{array}{l}\text { Karnes City - } \\
\text { Milam }^{7}\end{array}$ & -- & -- & -- & -- & -- & -- & -- & -- & -- & -- \\
\hline WW11 & $\begin{array}{l}\text { Karnes City - Main } \\
\text { Street }^{7}\end{array}$ & -- & -- & -- & -- & -- & -- & -- & -- & -- & -- \\
\hline WW12 & City of Kenedy ${ }^{8}$ & 1.51 & 1.47 & 1.66 & 1.68 & 1.57 & 1.40 & 1.45 & 1.80 & 1.71 & 1.72 \\
\hline WW13 & City of Goliad ${ }^{9}$ & 0.232 & 0.211 & 0.236 & 0.232 & 0.341 & 0.402 & 0.378 & 0.513 & 0.461 & 0.487 \\
\hline
\end{tabular}

${ }^{1}$ Sherry Pollock, City of Floresville, written commun., March 13, 2012.

${ }^{2}$ Christine Budnik, Cibolo Creek Municipal Authority, written commun., March 9, 2012.

${ }^{3}$ Randy Schwenn, City of Marion, written commun., March 19, 2012.

${ }^{4}$ Melissa Bryant, San Antonio River Authority, written commun., March 14, 2012.

${ }^{5}$ David Tillery, City of Stockdale, written commun., March 15, 2012.

${ }^{6}$ Lauren Sturm, City of Falls City, written commun., March 12, 2012.

7Information unavailable, Scott Barrientez, City of Karnes City, oral commun., April 4, 2012.

${ }^{8}$ Raymond Borroum, Veolia Water North America, written commun., March 16, 2012.

${ }^{9}$ Cindy Shilinga, City of Goliad, written commun., March 15, 2012. 
Table 7. Streamflow statistics for A, the period of record, and B, 2006-10, at U.S. Geological Survey streamflow-gaging stations in the lower San Antonio River, south-central Texas.

[USGS, U.S. Geological Survey; $\mathrm{mi}^{2}$, square miles; $\mathrm{ft}^{3} / \mathrm{s}$, cubic feet per second]

A. Statistics for available period of record

\begin{tabular}{|c|c|c|c|c|c|c|c|c|}
\hline Station name & $\begin{array}{c}\text { Site } \\
\text { number } \\
\text { (fig. 1) }\end{array}$ & $\begin{array}{l}\text { Period of } \\
\text { analysis }\end{array}$ & $\begin{array}{c}\text { Drainage } \\
\text { area } \\
\left(\mathrm{mi}^{2}\right)\end{array}$ & $\begin{array}{c}\text { Average } \\
\text { daily } \\
\text { streamflow } \\
\left(\mathrm{ft}^{3} / \mathbf{s}\right)\end{array}$ & $\begin{array}{c}\text { 80-percent } \\
\text { exceedance } \\
\text { streamflow } \\
\left(\mathrm{ft}^{3} / \mathrm{s}\right)\end{array}$ & $\begin{array}{c}\text { 50-percent } \\
\text { exceedance } \\
\text { streamflow } \\
\left(\mathrm{ft}^{3} / \mathrm{s}\right)\end{array}$ & $\begin{array}{c}\text { 20-percent } \\
\text { exceedance } \\
\text { streamflow } \\
\left(\mathrm{ft}^{3} / \mathrm{s}\right)\end{array}$ & $\begin{array}{c}\text { 10-percent } \\
\text { exceedance } \\
\text { streamflow } \\
\left(\mathrm{ft}^{3} / \mathrm{s}\right)\end{array}$ \\
\hline $\begin{array}{l}\text { San Antonio River near Elmendorf, } \\
\text { Tex. }\end{array}$ & $\mathrm{C} 1$ & $\begin{array}{c}10 / 1962- \\
12 / 2010\end{array}$ & 1,743 & 599 & 189 & 325 & 631 & 1,040 \\
\hline $\begin{array}{l}\text { San Antonio River near Floresville, } \\
\text { Tex. }\end{array}$ & $\mathrm{C} 2$ & $\begin{array}{c}01 / 2006- \\
12 / 2010\end{array}$ & 1,964 & 639 & 170 & 292 & 613 & 1,080 \\
\hline San Antonio River near Falls City, Tex. & $\mathrm{C} 3$ & $\begin{array}{c}05 / 1925- \\
12 / 2010\end{array}$ & 2,113 & 498 & 131 & 263 & 532 & 901 \\
\hline Cibolo Creek at Selma, Tex. & $\mathrm{C} 4$ & $\begin{array}{c}04 / 1946- \\
12 / 2010\end{array}$ & 274 & 26.7 & no flow & no flow & no flow & no flow \\
\hline Cibolo Creek near St. Hedwig, Tex. & $\mathrm{C} 5$ & $\begin{array}{c}12 / 2005- \\
12 / 2010\end{array}$ & 306 & 34.4 & 5.51 & 11.1 & 25.5 & 34.0 \\
\hline Martinez Creek near St. Hedwig, Tex. & C6 & $\begin{array}{c}11 / 2005- \\
12 / 2010\end{array}$ & 81.1 & 39.7 & 7.32 & 9.85 & 24.4 & 56.3 \\
\hline $\begin{array}{l}\text { Cibolo Creek at Sutherland Springs, } \\
\text { Tex. }\end{array}$ & $\mathrm{C} 7$ & $\begin{array}{c}07 / 1924- \\
12 / 2010\end{array}$ & 665 & 96.6 & 12.0 & 20.5 & 53.3 & 87.0 \\
\hline Cibolo Creek near Falls City, Tex. & $\mathrm{C} 8$ & $\begin{array}{c}10 / 1930- \\
12 / 2010\end{array}$ & 877 & 143 & 14.7 & 29.0 & 70.0 & 145 \\
\hline Ecleto Creek near Runge, Tex. & C9 & $\begin{array}{c}04 / 1962- \\
12 / 2010\end{array}$ & 239 & 36.9 & no flow & .480 & 6.00 & 21.4 \\
\hline San Antonio River at Goliad, Tex. & $\mathrm{C} 10$ & $\begin{array}{c}07 / 1924- \\
12 / 2010\end{array}$ & 3,921 & 784 & 182 & 356 & 769 & 1,340 \\
\hline San Antonio River near McFaddin, Tex. & $\mathrm{C} 11$ & $\begin{array}{c}11 / 2005- \\
12 / 2010\end{array}$ & 4,134 & 941 & 250 & 445 & 945 & 1,700 \\
\hline
\end{tabular}

B. Statistics for 01/2006-12/2010

\begin{tabular}{|c|c|c|c|c|c|c|c|c|}
\hline Station name & $\begin{array}{c}\text { Site } \\
\text { number } \\
\text { (fig. 1) }\end{array}$ & $\begin{array}{l}\text { Period of } \\
\text { analysis }\end{array}$ & $\begin{array}{c}\text { Drainage } \\
\text { area } \\
\left(\mathrm{mi}^{2}\right)\end{array}$ & $\begin{array}{c}\text { Average } \\
\text { daily } \\
\text { streamflow } \\
\left(\mathrm{ft}^{3} / \mathbf{s}\right)\end{array}$ & $\begin{array}{c}\text { 80-percent } \\
\text { exceedance } \\
\text { streamflow } \\
\left(\mathrm{ft}^{3} / \mathrm{s}\right)\end{array}$ & $\begin{array}{c}\text { 50-percent } \\
\text { exceedance } \\
\text { streamflow } \\
\left(\mathrm{ft}^{3} / \mathbf{s}\right)\end{array}$ & $\begin{array}{c}\text { 20-percent } \\
\text { exceedance } \\
\text { streamflow } \\
\left(\mathrm{ft}^{3} / \mathrm{s}\right)\end{array}$ & $\begin{array}{c}\text { 10-percent } \\
\text { exceedance } \\
\text { streamflow } \\
\left(\mathrm{ft}^{3} / \mathrm{s}\right)\end{array}$ \\
\hline $\begin{array}{l}\text { San Antonio River near Elmendorf, } \\
\text { Tex. }\end{array}$ & $\mathrm{C} 1$ & $\begin{array}{c}01 / 01 / 2006- \\
12 / 31 / 2010\end{array}$ & 1,743 & 599 & 164 & 302 & 635 & 1,030 \\
\hline $\begin{array}{l}\text { San Antonio River near Floresville, } \\
\text { Tex. }\end{array}$ & $\mathrm{C} 2$ & $\begin{array}{c}01 / 04 / 2006- \\
12 / 31 / 2010\end{array}$ & 1,964 & 639 & 170 & 292 & 613 & 1,080 \\
\hline San Antonio River near Falls City, Tex. & $\mathrm{C} 3$ & $\begin{array}{c}01 / 01 / 2006- \\
12 / / 312010\end{array}$ & 2,113 & 591 & 184 & 305 & 658 & 1,090 \\
\hline Cibolo Creek at Selma, Tex. & $\mathrm{C} 4$ & $\begin{array}{c}01 / 01 / 2006- \\
12 / 31 / 2010\end{array}$ & 274 & 23.1 & no flow & no flow & no flow & no flow \\
\hline Cibolo Creek near St. Hedwig, Tex. & $\mathrm{C} 5$ & $\begin{array}{c}01 / 01 / 2006- \\
12 / 31 / 2010\end{array}$ & 306 & 34.4 & 5.51 & 11.1 & 25.5 & 34.0 \\
\hline Martinez Creek near St. Hedwig, Tex. & C6 & $\begin{array}{c}01 / 01 / 2006- \\
12 / 31 / 2010\end{array}$ & 81.1 & 39.7 & 7.32 & 9.85 & 24.4 & 56.3 \\
\hline $\begin{array}{l}\text { Cibolo Creek at Sutherland Springs, } \\
\text { Tex. }\end{array}$ & $\mathrm{C} 7$ & $\begin{array}{c}01 / 01 / 2006- \\
12 / 31 / 2010\end{array}$ & 665 & 130 & 22.4 & 35.6 & 71.0 & 150 \\
\hline Cibolo Creek near Falls City, Tex. & $\mathrm{C} 8$ & $\begin{array}{c}01 / 01 / 2006- \\
12 / 31 / 2010\end{array}$ & 877 & 158 & 26.4 & 48.0 & 95.4 & 191 \\
\hline Ecleto Creek near Runge, Tex. & C9 & $\begin{array}{c}01 / 01 / 2006- \\
12 / 31 / 2010\end{array}$ & 239 & 34.4 & .043 & .573 & 7.94 & 23.6 \\
\hline San Antonio River at Goliad, Tex. & $\mathrm{C} 10$ & $\begin{array}{c}01 / 01 / 2006- \\
12 / 31 / 2010\end{array}$ & 3,921 & 879 & 256 & 424 & 931 & 1,490 \\
\hline $\begin{array}{l}\text { San Antonio River near McFaddin, } \\
\text { Tex. }\end{array}$ & $\mathrm{C} 11$ & $\begin{array}{c}01 / 01 / 2006- \\
12 / 31 / 2010\end{array}$ & 4,134 & 941 & 250 & 445 & 945 & 1,700 \\
\hline
\end{tabular}


Table 8. Estimation of streamflow gain or loss during 2006-10 using continuous streamflow-gaging stations in the lower San Antonio River watershed, south-central Texas.

[mi, miles; $\mathrm{mi}^{2}$, square miles; $\mathrm{ft}^{3} / \mathrm{s}$, cubic feet per second; $\mathrm{ft}^{3} / \mathrm{s} / \mathrm{mi}^{2}$; cubic feet per second per square mile; --, not applicable]

\begin{tabular}{|c|c|c|c|c|c|c|c|c|}
\hline Reach & $\begin{array}{l}\text { Stream } \\
\text { length } \\
\text { (mi) }\end{array}$ & $\begin{array}{l}\text { Contributing } \\
\text { drainage } \\
\text { area to } \\
\text { reach } \\
\left(\mathrm{mi}^{2}\right)\end{array}$ & $\begin{array}{l}\text { Average } \\
\text { daily } \\
\text { stream- } \\
\text { flow at } \\
\text { reach inlet } \\
\left(\mathrm{ft}^{3} / \mathrm{s}\right)\end{array}$ & $\begin{array}{c}\text { Aver- } \\
\text { age daily } \\
\text { streamflow } \\
\text { of measured } \\
\text { tributary } \\
\text { inflows } \\
\left(\mathrm{ft}^{3} / \mathrm{s}\right)\end{array}$ & $\begin{array}{l}\text { Permitted } \\
\text { return } \\
\text { flows } \\
\left(\mathrm{ft}^{3} / \mathbf{s}\right)\end{array}$ & $\begin{array}{l}\text { Permitted } \\
\text { diver- } \\
\text { sions } \\
\left(\mathrm{ft}^{3} / \mathrm{s}\right)\end{array}$ & $\begin{array}{c}\text { Average } \\
\text { streamflow } \\
\text { at reach } \\
\text { outlet } \\
\left(\mathrm{ft}^{3} / \mathbf{s}\right)\end{array}$ & $\begin{array}{c}\text { Estimated } \\
\text { streamflow } \\
\text { gain }(+) \text { or } \\
\text { loss }(-) \\
\left(\mathrm{ft}^{3} / \mathbf{s}\right)\end{array}$ \\
\hline $\begin{array}{l}\text { San Antonio River-Floresville to } \\
\text { Falls City (site C2 to C3, fig. 1) }\end{array}$ & 25.3 & 149 & 639 & no flow & no flow & 10 & 591 & -38 \\
\hline $\begin{array}{l}\text { Cibolo Creek-Selma to St Hedwig } \\
\text { (site C4 to C5, fig. 1) }\end{array}$ & 16.7 & 32.0 & 23.1 & no flow & 9.9 & 0.14 & 34.4 & 1.5 \\
\hline $\begin{array}{l}\text { Martinez Creek (headwaters to } \\
\text { site C6) }\end{array}$ & -- & 81.1 & no flow & no flow & 13 & 3.1 & 39.7 & 30 \\
\hline $\begin{array}{l}\text { Cibolo Creek-Sutherland Springs } \\
\text { to Falls City (site C7 to C8, } \\
\text { fig. 1) }\end{array}$ & 27.1 & 212 & 130 & no flow & 0.46 & 2.4 & 158 & 30 \\
\hline $\begin{array}{l}\text { Ecleto Creek (headwaters to } \\
\text { site C9) }\end{array}$ & -- & 239 & no flow & no flow & no flow & no flow & 34.4 & 34 \\
\hline $\begin{array}{l}\text { San Antonio River-Falls City to } \\
\text { Goliad (site C3 to C10, fig. 1) }\end{array}$ & 85.2 & $\begin{array}{c}1,808 \\
(1,066 \text { gaged })^{4}\end{array}$ & 591 & ${ }^{4} 192$ & 27 & 19 & 879 & 88 \\
\hline $\begin{array}{l}\text { San Antonio River-Goliad to } \\
\text { McFaddin (site C10 to C11, } \\
\text { fig. 1) }\end{array}$ & 54.2 & 213 & 879 & no flow & no flow & no flow & 941 & 62 \\
\hline
\end{tabular}

${ }^{1}$ Permitted discharge amounts and locations from U.S. Environmental Protection Agency (2010).

${ }^{2}$ Surface-water right diversion amounts and locations from Texas Commision on Environmental Quality (2010; 2011a).

${ }^{3}$ Measured inflows are gaged at Martinez Creek near Saint Hedwig, Tex.

${ }^{4}$ Measured inflows are gaged at Ecleto Creek near Runge, Texas, and Cibolo Creek near Falls City, Tex. 
Table 9. Estimated streamflow gains and losses for the main stem of the lower San Antonio River, south-central Texas, $2006-7$.

[Bold font indicates gain or loss greater than the potential measurement error and discrete measurements outside the range of the hourly continuous measurements at the upstream station; mi, miles; $\mathrm{mi}^{2}$, square miles; $\mathrm{ft}^{3} / \mathrm{s}$, cubic feet per second; na, not available; --, not applicable]

\begin{tabular}{|c|c|c|c|c|c|c|c|}
\hline $\begin{array}{l}\text { Reach } \\
\text { (fig. 2) }\end{array}$ & $\begin{array}{c}\text { Site } \\
\text { identifier } \\
\text { (fig. 1, table 1) }\end{array}$ & $\begin{array}{c}\text { Streamflow } \\
\left(\mathrm{ft}^{3} / \mathrm{s}\right)\end{array}$ & $\begin{array}{c}\text { Range of hourly } \\
\text { streamflow } \\
\left(\mathrm{ft}^{3} / \mathrm{s}\right)\end{array}$ & $\begin{array}{c}\text { Average streamflow } \\
\text { of measured } \\
\text { tributary inflows } \\
\left(\mathrm{ft}^{3} / \mathrm{s}\right)\end{array}$ & $\begin{array}{l}\text { Return } \\
\text { flows } \\
\left(\mathrm{ft}^{3} / \mathrm{s}\right)\end{array}$ & $\begin{array}{c}\text { Potential } \\
\text { measurement } \\
\text { error } \\
\left(\mathrm{ft}^{3} / \mathbf{s}\right) \\
\end{array}$ & $\begin{array}{c}\text { Estimated } \\
\text { streamflow } \\
\text { gain }(+) \\
\text { or loss }(-) \\
\end{array}$ \\
\hline & $\mathrm{C} 1$ & 103 & 84.4 to 121 & & & 15.5 & \\
\hline 1 & & & & no flow & 0.85 & 25.4 & 20.1 \\
\hline \multirow[t]{2}{*}{2} & & & & no flow & no flow & 20.0 & 2.00 \\
\hline & D3 & 126 & -- & & & 10.1 & \\
\hline \multirow[t]{2}{*}{3} & & & & no flow & no flow & 23.6 & 9.00 \\
\hline & $\mathrm{C} 3$ & 135 & 123 to 145 & & & 13.5 & \\
\hline 4 & & & & no flow & no flow & 23.4 & -11.0 \\
\hline \multirow[t]{2}{*}{6} & & & & 1.5 & no flow & 25.3 & 6.50 \\
\hline & D14 & 162 & -- & & & 13.0 & \\
\hline \multirow[t]{2}{*}{7} & & & & no flow & no flow & 25.4 & -7.00 \\
\hline & D15 & 155 & -- & & & 12.4 & \\
\hline \multirow[t]{2}{*}{8} & & & & no flow & no flow & 26.1 & 16.0 \\
\hline & D16 & 171 & -- & & & 13.7 & \\
\hline \multirow[t]{2}{*}{9} & & & & 0.15 & 0.22 & 26.4 & -12.4 \\
\hline & $\mathrm{C} 10$ & 159 & 153 to 165 & & & 12.7 & \\
\hline 10 & & & & 0.11 & no flow & 27.9 & 30.9 \\
\hline \multicolumn{8}{|c|}{ August 23-24, 2006} \\
\hline 1 & $\mathrm{C} 2$ & 113 & 95.7 to 126 & & & 11.3 & \\
\hline \multirow[t]{2}{*}{2} & & & & no flow & no flow & 22.1 & 22.0 \\
\hline & D3 & 135 & -- & & & 10.8 & \\
\hline \multirow[t]{2}{*}{3} & & & & no flow & no flow & 21.1 & -32.0 \\
\hline & $\mathrm{C} 3$ & 103 & 95.0 to 111 & & & 10.3 & \\
\hline \multirow[t]{2}{*}{4} & & & & no flow & no flow & 18.8 & 3.00 \\
\hline & D5 & 106 & -- & & & 8.48 & \\
\hline \multirow[t]{2}{*}{5} & & & & 12 & no flow & 21.2 & 18.1 \\
\hline & D11 & 136 & -- & & & 10.9 & \\
\hline \multirow[t]{2}{*}{6} & & & & 2.1 & no flow & 20.9 & -13.1 \\
\hline & D14 & 125 & -- & & & 10.0 & \\
\hline \multirow[t]{2}{*}{7} & & & & no flow & no flow & 20.5 & 6.00 \\
\hline & D15 & 131 & -- & & & 10.5 & \\
\hline 8 & & & & no flow & no flow & 21.3 & 4.00 \\
\hline
\end{tabular}


Table 9. Estimated streamflow gains and losses for the main stem of the lower San Antonio River, south-central Texas, 2006-7.Continued

[Bold font indicates gain or loss greater than the potential measurement error and discrete measurements outside the range of the hourly continuous measurements at the upstream station; mi, miles; $\mathrm{mi}^{2}$, square miles; $\mathrm{ft}^{3}$ /s, cubic feet per second; na, not available; --, not applicable]

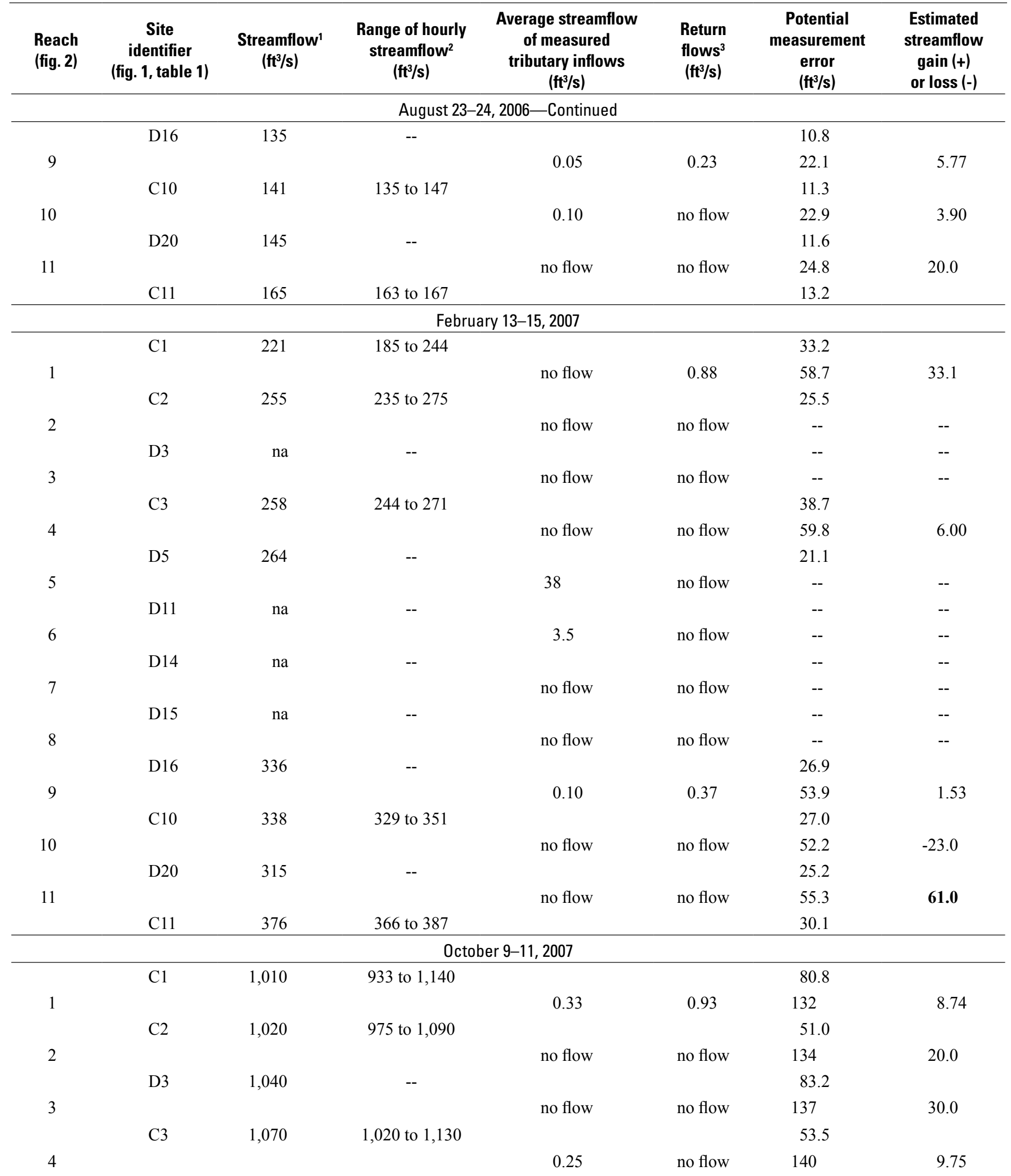


Table 9. Estimated streamflow gains and losses for the main stem of the lower San Antonio River, south-central Texas, 2006-7.Continued

[Bold font indicates gain or loss greater than the potential measurement error and discrete measurements outside the range of the hourly continuous measurements at the upstream station; mi, miles; $\mathrm{mi}^{2}$, square miles; $\mathrm{ft}^{3} / \mathrm{s}$, cubic feet per second; na, not available; --, not applicable]

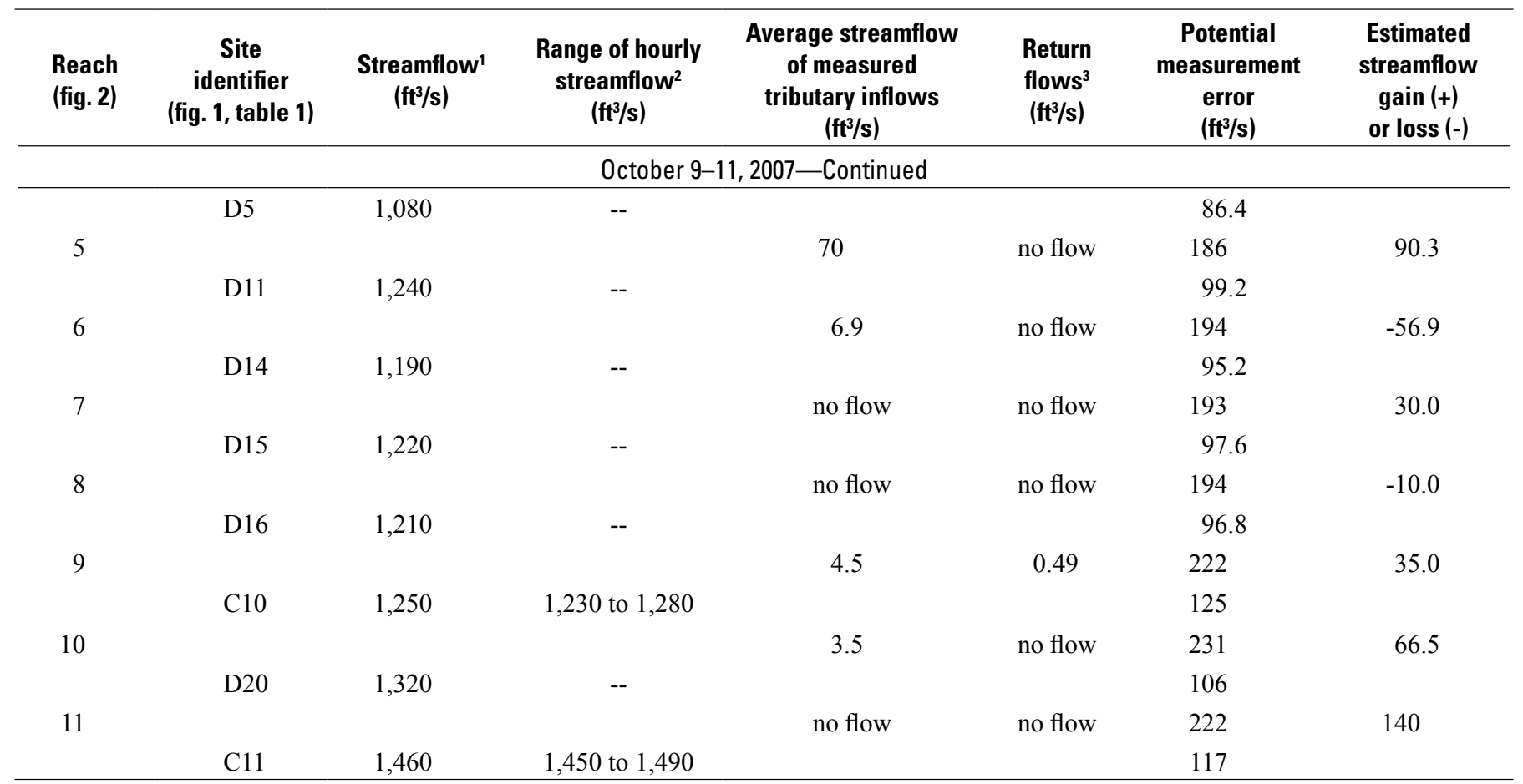

${ }^{1}$ Streamflow at continuous record streamflow-gaging stations computed as the average of the daily values over the synoptic periodor the result of the flow measurement at the discrete measurement locations (table 1).

${ }^{2}$ Ranges of hourly streamflows measured at the U.S. Geological Survey continuous streamflow-measurement stations (table 1).

${ }^{3}$ Wastewater discharges computed as the average of the daily values over the synoptic period. 
Table 10. Estimated streamflow gains on the main stem of the lower San Antonio River, from Elemendorf, Texas, to Goliad, Tex., and from Goliad Tex., to McFaddin, Tex., south-central Texas, 2006-7.

[Bold font indicates gain or loss greater than the potential measurement error; mi, miles; $\mathrm{mi}^{2}$, square miles; $\mathrm{ft}^{3} \mathrm{~s}$, cubic feet per second; nm, not measured]

\begin{tabular}{|c|c|c|c|c|c|c|}
\hline $\begin{array}{c}\text { Site } \\
\text { identifier } \\
\text { (fig. 1) }\end{array}$ & $\begin{array}{c}\text { Streamflow } \\
\left(\mathrm{ft}^{3} / \mathbf{s}\right)\end{array}$ & $\begin{array}{c}\text { Range of } \\
\text { hourly } \\
\text { streamflow } \\
\left(\mathrm{ft}^{3} / \mathbf{s}\right)\end{array}$ & $\begin{array}{c}\text { Average } \\
\text { streamflow } \\
\text { of measured } \\
\text { tributary inflows } \\
\left(\mathbf{f t}^{3} / \mathbf{s}\right)\end{array}$ & $\begin{array}{c}\text { Return } \\
\text { flows } \\
\left(\mathbf{f t t}^{3} / \mathbf{s}\right)\end{array}$ & $\begin{array}{c}\text { Potential } \\
\text { measurement } \\
\text { error } \\
\left(\mathbf{f t}^{3} / \mathbf{s}\right)\end{array}$ & $\begin{array}{c}\text { Estimated } \\
\text { streamflou } \\
\text { gain }(+) \text { or } \\
\text { loss }(-)\end{array}$ \\
\hline \multicolumn{7}{|c|}{ April 18-19, 2006} \\
\hline \multirow[t]{2}{*}{$\mathrm{C} 1$} & 103 & 84.4 to 121 & & & 15.5 & \\
\hline & & & 23.7 & 16.8 & 28.2 & 15.5 \\
\hline \multirow[t]{2}{*}{$\mathrm{C} 10$} & 159 & 153 to 165 & & & 12.7 & \\
\hline & & & 0.110 & no flow & 28.8 & 41.9 \\
\hline $\mathrm{C} 11$ & 201 & 194 to 203 & & & 16.1 & \\
\hline \multicolumn{7}{|c|}{ August 23-24, 2006} \\
\hline \multirow[t]{2}{*}{$\mathrm{C} 1$} & 109 & 86.7 to 127 & & & 16.4 & \\
\hline & & & 14.0 & 16.6 & 27.6 & 1.43 \\
\hline \multirow[t]{2}{*}{$\mathrm{C} 10$} & 141 & 135 to 147 & & & 11.3 & \\
\hline & & & 0.100 & no flow & 24.5 & 23.9 \\
\hline $\mathrm{C} 11$ & 165 & 163 to 167 & & & 13.2 & \\
\hline \multicolumn{7}{|c|}{ February 13-15, 2007} \\
\hline \multirow[t]{2}{*}{$\mathrm{C} 1$} & 221 & 185 to 244 & & & 33.2 & \\
\hline & & & 41.1 & 18.4 & 60.2 & 57.4 \\
\hline \multirow[t]{2}{*}{$\mathrm{C} 10$} & 338 & 329 to 351 & & & 27.0 & \\
\hline & & & no flow & no flow & 57.1 & 38.0 \\
\hline $\mathrm{C} 11$ & 376 & 366 to 387 & & & 30.1 & \\
\hline \multicolumn{7}{|c|}{ October 9-11, 2007} \\
\hline \multirow[t]{2}{*}{$\mathrm{C} 1$} & 1,010 & 933 to 1,140 & & & 80.8 & \\
\hline & & & 81.7 & 19.4 & 206 & 139 \\
\hline \multirow[t]{2}{*}{$\mathrm{C} 10$} & 1,250 & 1,230 to 1,280 & & & 125 & \\
\hline & & & 3.50 & no flow & 242 & 207 \\
\hline $\mathrm{C} 11$ & 1,460 & 1,450 to 1,490 & & & 117 & \\
\hline
\end{tabular}

${ }^{1}$ Streamflow at continuous record streamflow-gaging stations computed as the average of the daily values over the synoptic period.

${ }^{2}$ Wastewater discharges computed as the average of the daily values over the synoptic period. 
Table 11. Estimated streamflow gains and losses on the main stem of lower Cibolo Creek, Texas, 2006-7.

[Bold font indicates gain or loss greater than the potential measurement error and discrete measurements outside the range of the hourly continuous measurements at the upstream station; mi, miles; $\mathrm{mi}^{2}$, square miles; $\mathrm{ft}^{3} / \mathrm{s}$, cubic feet per second; nm, not measured; --, not applicable]

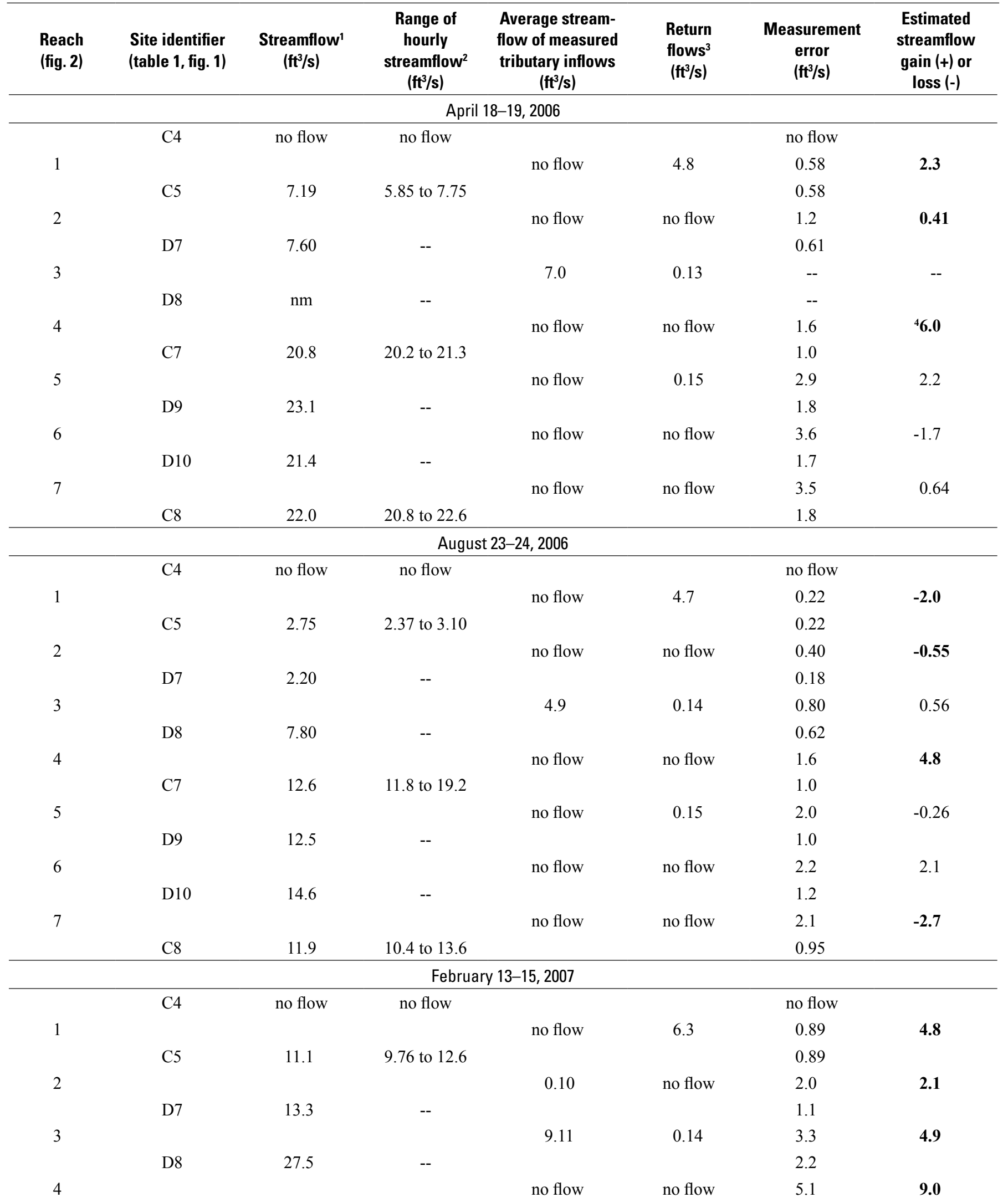


Table 11. Estimated streamflow gains and losses on the main stem of lower Cibolo Creek, Texas, 2006-7.-Continued

[Bold font indicates gain or loss greater than the potential measurement error and discrete measurements outside the range of the hourly continuous measurements at the upstream station; mi, miles; $\mathrm{mi}^{2}$, square miles; $\mathrm{ft}^{3} / \mathrm{s}$, cubic feet per second; $\mathrm{nm}$, not measured; --, not applicable]

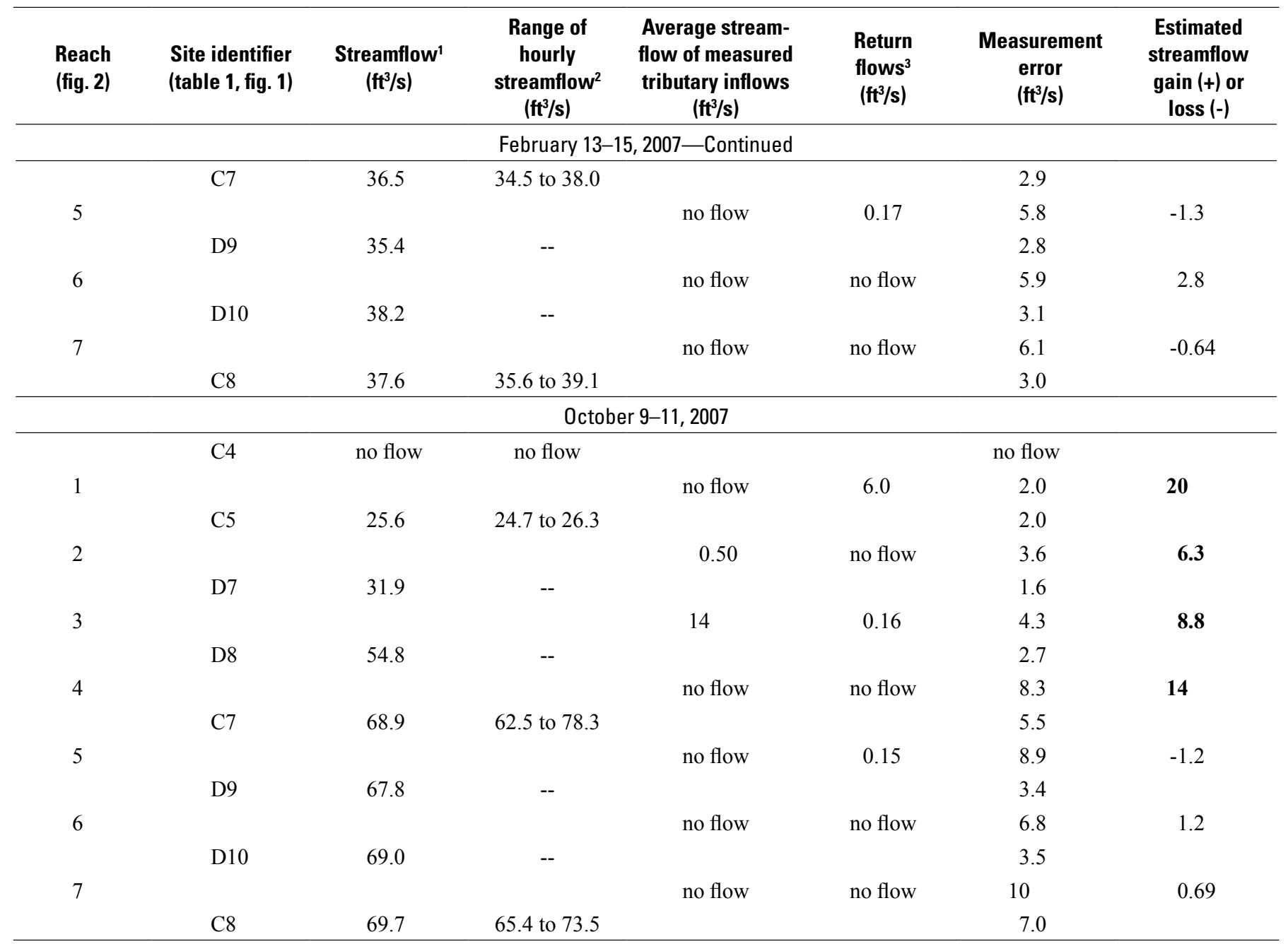

${ }^{1}$ Streamflow at continuous record streamflow-gaging stations computed as the average of the daily values over the synoptic period or the result of the flow measurement at the discrete measurement locations (table 1).

${ }^{2}$ Ranges of hourly streamflows measured at the U.S. Geological Survey continuous streamflow-measurement stations (table1).

${ }^{3}$ Wastewater discharges computed as the average of the daily values over the synoptic period.

${ }^{4}$ Results compiled for reaches 3 and 4, D7 to C7.

Publishing support provided by

Lafayette Publishing Service Center

Information regarding water resources in Texas is available at

http://tx.usgs.gov/ 

